G. B. LULL, State Forester.

“N UO-OPERAT:ION WITH THE FOREST SERVICE, U. S. DEPT. AGRICULTURE.
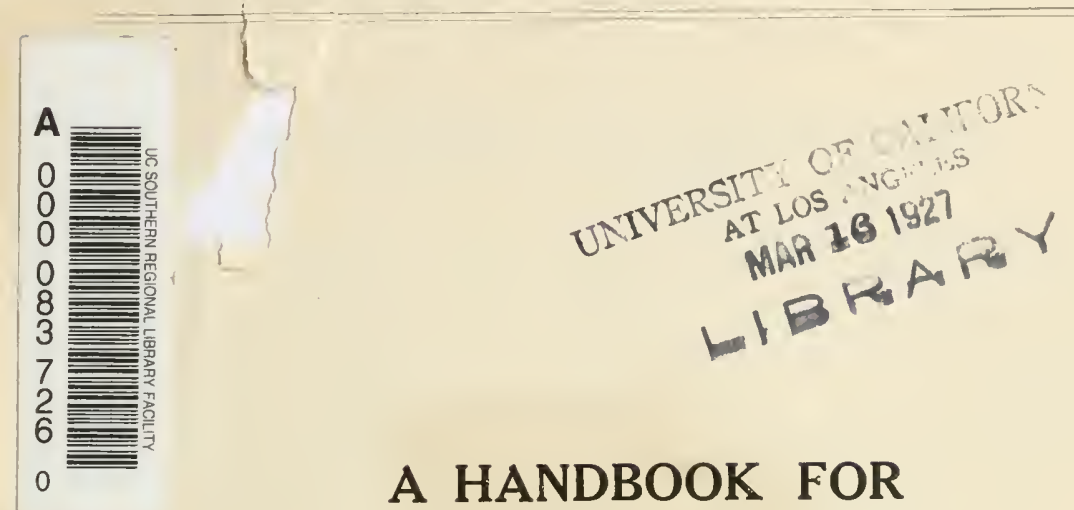

\title{
A HANDBOOK FOR
}

\section{EUCALYPTUS PLANTERS}

University of California

Southern Regional

Library Facility

(SECOND EDITION.)

SACRAMENTO: 


\section{STATE BOARD OF FORESTRY.}

JAMES N. GILLETT Governor.

CHAS. F. CURRY Secretary of State.

U. S. WEBB Attorney-General.

G. B. LULL State Forester.

PROVISION FOR CO-OPERATIVE WORK.

Section 4. The State Forester shall, upon request and whenever he deems it essential to the best interests of the people and the State, co-operate with counties, towns, corporations and individuals in preparing plans for the protection, management and replacement of trees, woodlots and timber tracts, on consideration and under an agreement that the parties obtaining such assistance pay at least the field expenses of the men employed in preparing said plans.-Stat. 1905:235. 


\section{CONTENTS.}

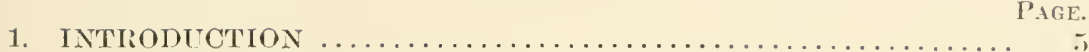

2. HISTORY OF EUCALYPTUS IN CALIFORNIA........... 5

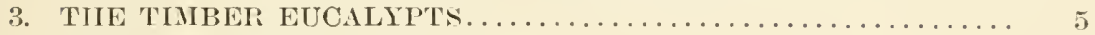

4. SILVICAL CHARACTERISTICS..................

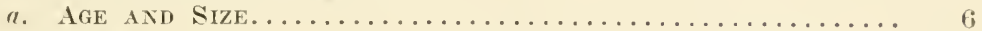

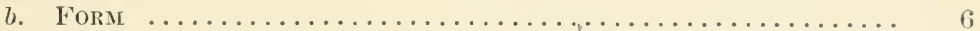

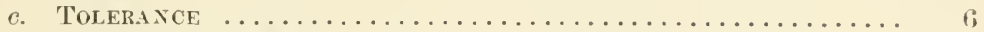

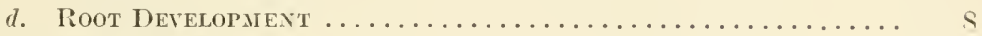

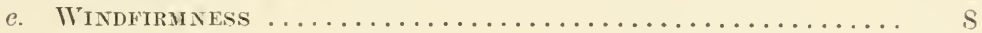

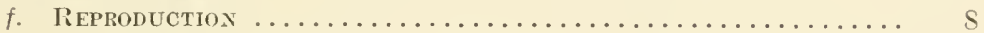

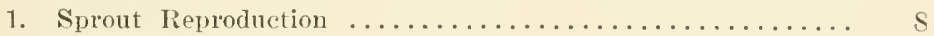

2. Seed Reproduction ......................

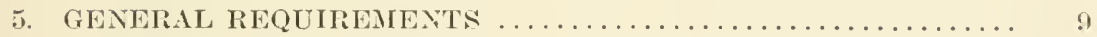

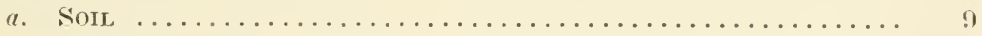

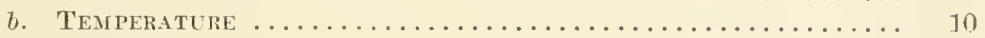

c. Moisture ....................................... 10

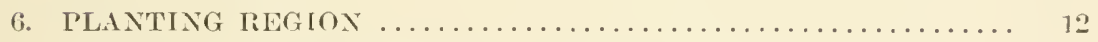

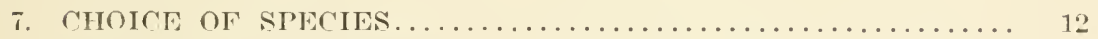

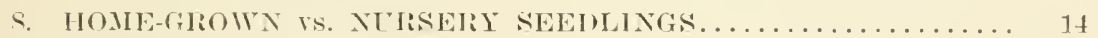

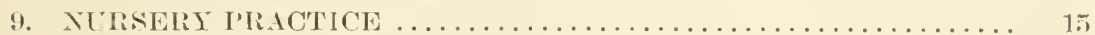

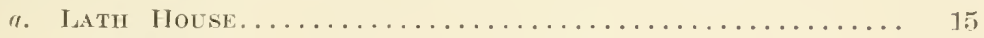

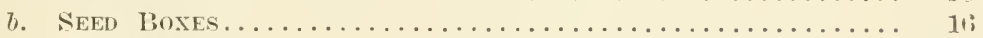

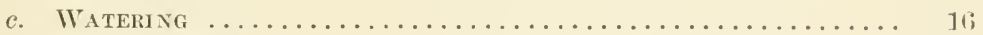

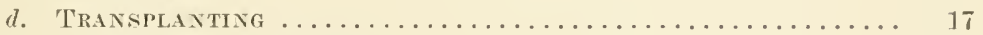

c. Protection of NuRsert............................ 17

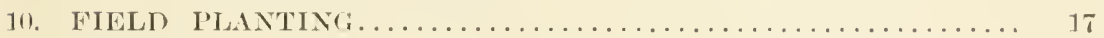

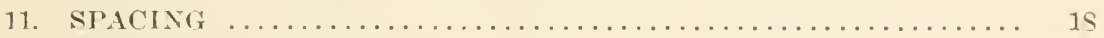

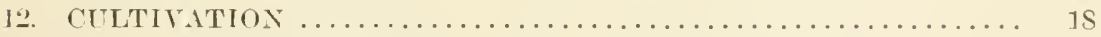

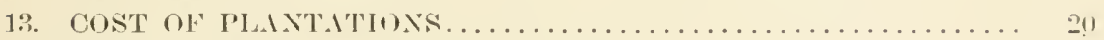

14. PROTECTION . . . . . . . .

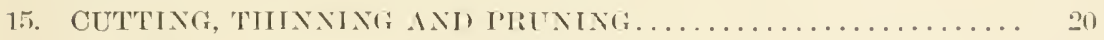

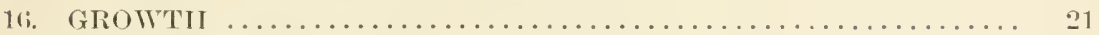

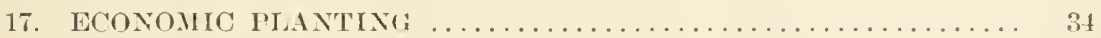

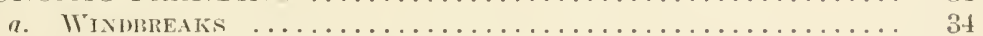

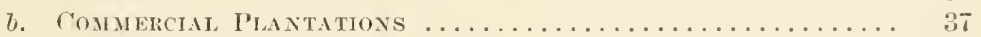

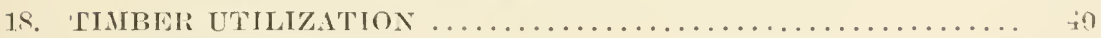

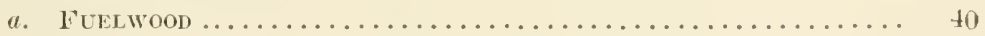

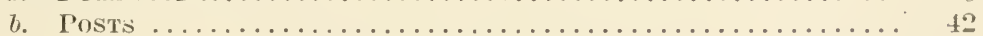

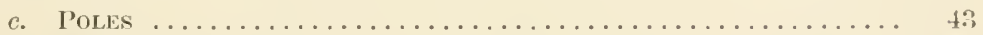

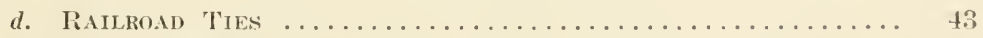

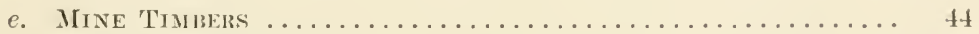

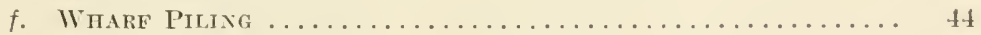

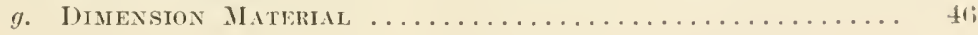




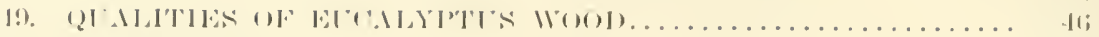

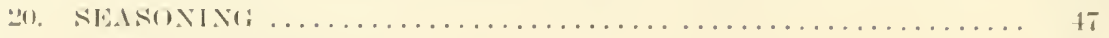

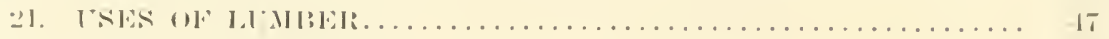

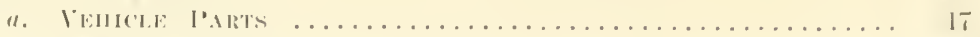

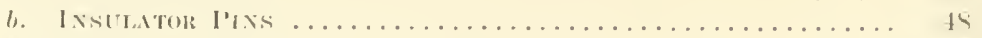

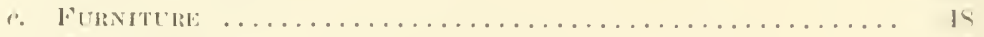

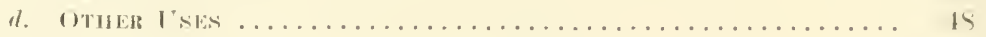

2.). 


\section{A HANDBOOK FOR EUCALYPTUS PLANTERS.}

INTRODI CTION.

The growing interest in forest planting in California makes it desirable that prospective planters be supplied with concise information regarding the demands and qualities of the genus Encalyptus, which. owing to its rapid growth and wide adaptation to economic uses, is destined to be planted more extensively than any other tree. Reliable information on this genns is now obtainable in Bulletin No. 35 of the Forest Service but the information contained is more general in nature than the typical, qnick-action planter is willing to digest. More recently a detailed, thongh as ret unpublished, report on the planting of the commercial encalypts has been made by S. J. Flinthan of the Forest Service after a study conducted in coöperation with the State of California. The essentials for planter's have been anlled from this report and other sonrces and embodied in this cireular to meet the great demand for specific information on the economies of Eucalyptus planting.

\section{HISTORY OF EUC.ALYPTLS IN C.LIFORNIA.}

The encalypts are exotics in California, haring been introduced from sustralia in the early fifties by travelers who were impressed with the splendid proportions and rapid development of the genus in its native habitat. They were first planted in the ricinity of San Francisco for ormamental purposes. Later. in the sixties, they were planted near Los Angeles. The rapid growth and complete adaptability of the exotic to its new enviromments instantly claimed the attention of murserymen. who recognized its suitability for commervial planting. Between 1870 and 1875 considerable planting was done for fuel. windbreaks and shade along aremuse One of these early groves was established near Irvington in the Sinta Clara Valley in 1870. and later, 1872 and 1873. the first plantation in Southern California was made by Hon. Ellwond cooper on his ranch near Santa Barbara. The well-known Widney and Nadean grores. set ont in $187 t$ and 1875. were the first extensive plantations made near Los Angeles.

THE THBER EIC.MLYTS.

Encalyptus has deservedly elained more attention than any othere exotic gemus, and probably more than mest of those indigenoms to the Lnited States. Great energy and persistenee in experimenting with 
the genus have been manifested by murserymen and pioneer planters rver since its introdurtion. More than 150 speries have been irlentified by botanists who have studied the Australian forests. Fully 100 of these. including practically all the speries considered valuable for timher, have been introdıred and planted in C'alifornia.

Fol general purposes, however, the blue gum has been used more extensively than all other species combined, and even to-day the knowledge of most laymen of the eucalypts is confined to their arquaintance with this species. Several other species, however, possess special qualities which warrant their selection for particular uses and for certain localities. Among these are the sugar, manna, gray, red and lemon guns, which, with the blue gum, owing to their rapid growth and splendid development, rank as the timber euealypts.

\section{SYLVICAL CILARACTERISTICS.}

Age and size. In Australia the euralypts reach ages of from 400 to 500 years, and dimensions second only to the California Sequoias. Indeed, in height development, though not in diameter. they surpass them. Nany speeies are said to reach heights from 300 to over 400 feet, and diameters exceeding 12 to 15 feet. These dimensions result from long periods of growth in the virgin forests, however, and no such sizes have yet been attained by eucalypts planted in California.

No encalypt has grown to greater age than 40 years in this State. At this age the period of rapid development has not been passed. and no disposition to become short-lived is shown, as is frequently the case with species grown outside their habitat. Blue gum trees 175 feet in height and 5 or 6 feet in diameter have been produced here in from twenty-four to thirty years. The single quality, rapidity of growth, entitles the encalypts to serious consideration. for no other species can attain like dimensions in five times this period.

Form. Naturally the timber encalypts maintain an erect form. with strong main axes and slender limbs. Young trees shoot up rapidly into slender poles with scantily branched crowns and feathery, drooping foliage. The bole gradually clears of limbs. particularly where the density of the stand canses lateral shading. Open-grown timber has more numerons and larger limbs.

Tolerance. The timber eucalypts are species of moderate shade endurance. During their early growth they will bear more shade than later in life. The seedlings are even shade-demanding, and succeed best under partial shade. When growth has commenced, howerer. full light should be afforded them. 
The intolerance of saplings and poles is well iudicated by their rapid height growth. upon which they depend in competition to escape sup-

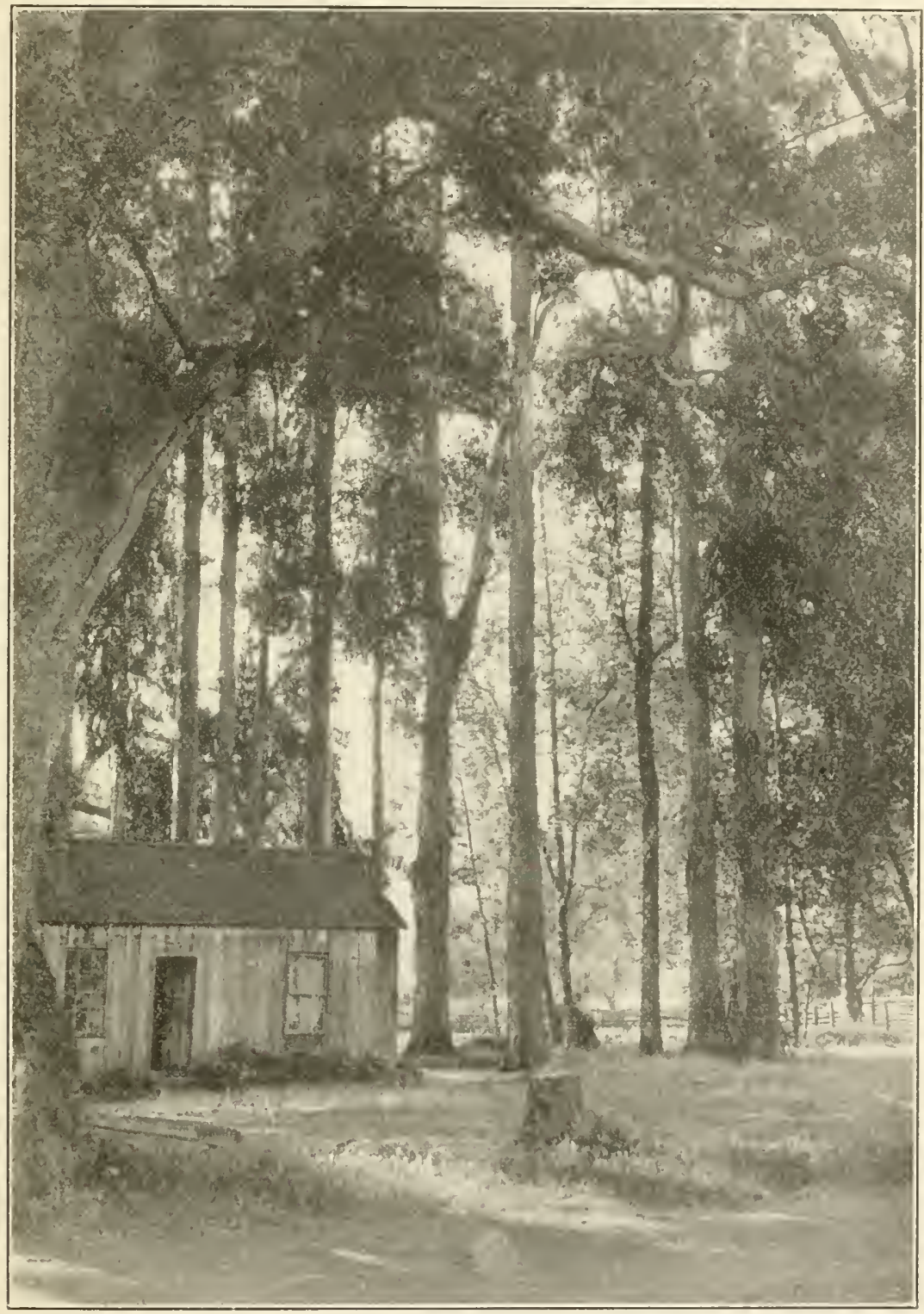

PLATE 1. Blue gum timber 24 years old, showing characteristic clear, straight growth of this species. Trees over 36 inches in diameter, 175 feet tall, and 100 to 120 feet clear.

pression. It is not uncommon to see saplings too spindling to stand erect. caused by their efforts to overtop a competitor for light. 


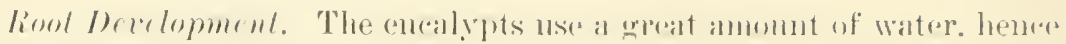
they prefer a leep soil, thromgh which the roots may penct rate to lower

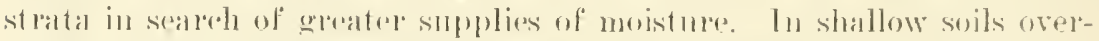
lying rock or hardpan the routs ale foreed to spreat laterally and on such situations the grewth is gemerally stunted and slow.

In arly gears root development is exceedingly rapirl, that of romne

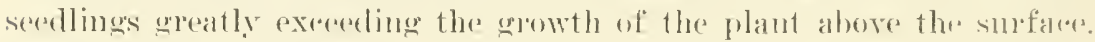
During ardy erowli most encalypts send down a taploot as well as numerous spreading laterals. The taprout of the hlue gimm, at least. ramely peretrates to a depth grater than fi feet. further derelopment being ancentrated in the strong laterals.

The roots exhibit a strong impulse to seck water. and to reach it somestimes extend over 100 feet, arossing meler litehes, parements mut roads. If they gain arcess to pipes or ditches through raloks or breaks in the" masonry, they send ont large masses of small foreling roots. C'isterns and water-pipes have been completely cloguged in this mamner.

Hindfirmmess. The production of an extensive lateral root sistem renders the encalypts very windfirm. Their strong anchorage in the soil. combined with the flexibility of the growing stem. lenders them particularly valuable for windbreak purposes. since a break which will yield before the force of the wind tends to deflect the air comrents upward. and protects areas far to leeward. whereas an mnielding barrier breaks the wind only on areas in close proximity to it.

Reproduction. The complete adaptability of the eucalypts to California is especially shown by their strong reproduction here by both seed and sprouts.

Sprout Reproduction. All the encalypts planted in California spront vigorously from the stmmp or roots after antting or in response to any injury to the tree. The small trees in yomn plantations generally sprout up thriftily after they have been ant bark hy animals or after saplings have been killed to the ground by frost or fire. After fire injury also, in an attempt at refoliation. the stems generally clothe themselves thickly from the gromel to the top with short sprout branches like fire-injured redwoods.

Whenever it is desirable to reproduce a species which possesses (on)picing rualities adrantage is generally taken of them. With most species. however, the sprouts produced after the third or fourth cutting are loss thrifty than those after the first or serond. This tendencry to waken seems absent in the monlypts. or if present. coppioing has not been practiced hom enomgh in California to reveal it. Fuelwom 
groves have sprouted up rigorously after the fourth and fifth cutting. and seedling trees over thirty rears old sprout after cutting as thriftily as young trees. Indeed, it is almost impossible to kill the stmmps of old trees or to prevent the sprouting of old roots left in the gromend after the stmmps have been grubbed ont.

Secd Reproduction. Since natural regeneration is not practiced. the natural seeding of eucalypts is of little commeroial importance. Seed is produced abundantly by all the eucalypts introduced into California. The fruit generally lemains on the trees, mopened. nntil the fall of the seed cases to the ground. Wind dissemination plays no part in the axtension of Encalyptus. and as the seeds are not eaten by birds, the seedlings always occur beneath or very near the parent tree.

\section{GENERAL REQLIREMENTS.}

Every species makes definite ecological demands mpon its habitat. The optinmm development of a species is contingent upon the fulfillment of its requirements. It senerally happens. however. that the demands of a species are not inflexible, and the specjes will smrvive if its requirements are but partially met. For example. a speries will survive and grow indifferently, if it receives less fool or light than it requires for best development. In the case of temperature much depends upon the age and condition of the tree species at the time its normal temperature range is crossed. If it is thriving and the temperature change comes gradually it will frequently withstand the shork withont injury. Under less favorable conditions it will not recover. Except upon temperature the demands of encalypts are fairly Hexible. Their thermal demands, howerer. must he met. Whenerer Encalyptus planting is modertaken outside the thermal range of the speries nsed some loss must be expeeted. Where only small plantatious are made a risk is generally warlanted. But where extensive commereial plantations, involving heary expense. are made, they should lie within the thermal range of the species used. Since this comoular deals with the commercial production of encalypts, the planting of any speries will not be recommended ontside its themal range. It is probable that most of the speries treated will grow, indifferently at least. comsitorably ontside of the range where their planting will he advised.

Soil. Practically. all the encalypts grow hest on a deep. fortile, welldrained, loam soil. But, as more valuable (•lops likew ise derolop nost successfully there. the necessity aldises of fincling similar ar proorer rlasses of land. which, on account of inaressibility. or romelnmess. 
is not of fisst value for arricultural purposes. These abound in the valleys and on the slopes of the lower hills throughout California. The chemical romposition of the soil is of little importance, so long as an cxuss of injurioms chemicals does not o*"ur. The physiral properties of the soil, such as permeability, retentiveness, ete, are vastly more important.

Temperature. No one factor has so much influence in goveruing the extension of Encalyptus as temperature. The fact that its planting range is practically restricted to California is wholly attributable to the frost-tenderness of the genus. During the seedling years the danger from frost is gratest. The susceptibility of the sugar gum seedlings to frost injury is particularly marked.

'Thermometer readings of temperature are not always true indices of the influence of frost on a tender plant. Much depends upon the condition of the plant at that particular time. If a period of warm weather is followed by a sudden drop in temperature, the plant suffers more than it would if an equally low temperature had come gradually. The exposure of the plantation is likewise important. If the plantation has an eastern exposure where it is reached by the first rays of the sun, the damage will be greater than if it remains in partial shade while the temperature ascends slowly.

The following order indicates the frost-hardiness of the timber encalypts very closely: Red, gray. manna, blue, sugar, and lemon gum.

Woisture. A rapid growing plant, like anything else which grows rapidly, requires lots of food. This is taken up by the roots in the form of mineral salts in solution and elaborated in the leaves. Hence. the tree can not get its food unless its roots ran obtain water. Therefore, other conditions being equal, the rate of growth depends directly on the amount of water the plant secures. While encalypts will grow where the soil moisture is deficient, the rate of growth will be mucls slower than where the tree gets all it needs. For commercial purposes it is unwise to attempt to produce Eucalyptus where the soil moisture is markedly deficient. A fairly retentive, deep soil which receives an annual rainfall of from 25 to 30 inches will produce grood trees.

Deficient soil moisture is supplemented by atmospheric moisture in the fog belt, where the fog is condensed by contact with the foliage. During a heavy fog the foliage of gum trees drips as if from a shower. and the ground under the trees becomes soaked overnight. The occurrence of fog accounts largely for the excellent growth of Eucalyptus on sandy soil at the Presidio, on the Piedmont Hills, and elsewhere in situations, otherwise inhospitable, throughout the Bay counties. Fogs, likewise. make the Los Angeles plain one of the farorable regions in 
the State for Encalyptus culture, although less so than the Bay counties, owing to lesser precipitation.

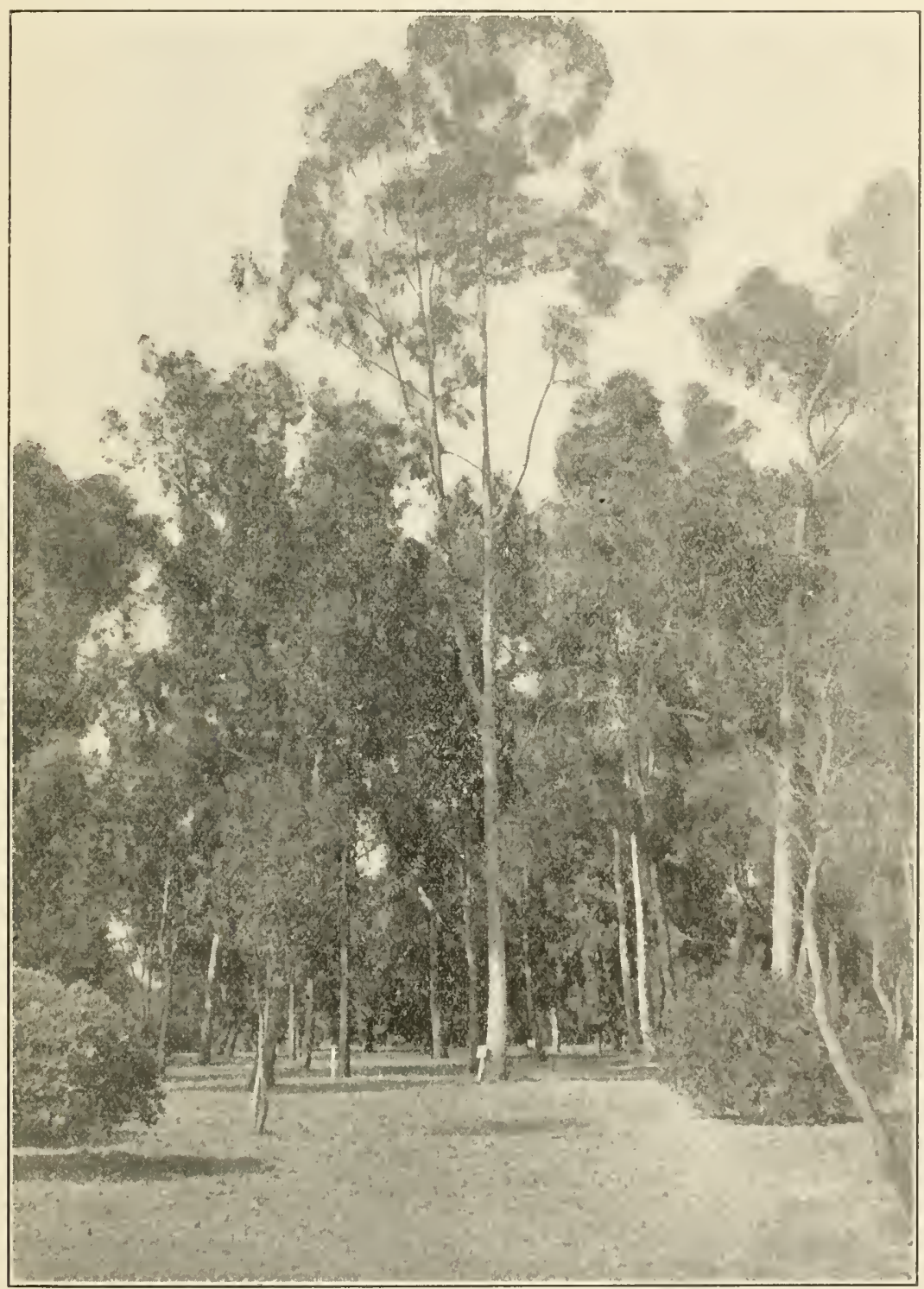

PLATE 2. Gray gum tree about 20 rears old in an experimental plantation. Tree grown in an unfavorable situation to a height of over 100 feet and a diameter of 14 inches.

Among the timber eucalypts some are able to thrive on less moisture than others. The following order indicates their relative droughthardiness: Sugar, red, gray, manna, lemon, and blue gum. 
PIANTING REGIONS.

The area within which the timber ancalypts male be successfolly propagated has been hroally defiued as that bomeded by the forost line. The manna and gray gums may be safely planted when the temperature does not drop helom 2.2 F. This area is shown. appoximately. he the

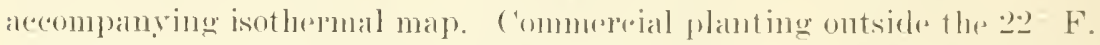
isotherms is not recommended lor any spereses, nor outside the efi F. and 28 F. isotherms for blue and sugar gums, respertively.

For suceesstul growth the rexpirements of encalypts for soil and

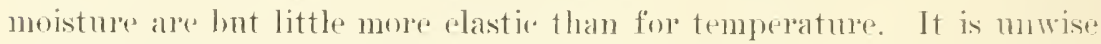
to set high-priced seedlings on shallow soil or where the water table is far below the surface. Planters shonld not forget that the rapid growth and proper development of emalypts is contingent on their food supply rather than on any inherent quality. Where the water table is aceessible at not more than 25 fret below the surface. unoul growth may be expected. .

CHOICE OF SPECIES.

Generally speaking. the bhe and sugar gums shomld be rhosen for planting within their thermal ranges. Ontsicle these the red. way and manna gums must be tonsidered as the leading species.

Whenever the selertion of species lies between blue and sngar gmm. the kind of product desired and the amount of soil moisture present nust determine the choice. If firewood, piles, or dimension stutf is desired, the blue gmm should be selected. especially if there is no marked deficiency of soil moisture. If poles, ties or a mood of mmsual durability and strength is desired the sugar gum should be chosen, particularly if the situation is rather arid. 'The sugar gum is the more dronght-pesisting, but the blue gum is the more rapid-growing.

Ontside the planting range of the hlue and sugar gums the red sum commends itself, owing to its frost-hardiness and the durability of its timber. In frosty or swampy locations it shonld receive first preference. The uses of its product are limited. however. by the fact that it is inclined to a cooked. branchy form. It is of rapid growth and furnishes a product which is very durable in contact with the soil.

The gray gum is equally rapid in growth. hut is somewhat lesis frostbardy than the red. It grows in good form. esperially in plantations. and fumishes a very durable timber.

Manma gum gows very rapidly, but it is hardly worthy of consideration. since it is but slightly more frost-hardy than the sugar and hine gums. while its timber is inferior to that of either species.

Lemon gim is probably more valuable for ormamental than for economic planting. Its rate of erowth is abont erpual to that of red 


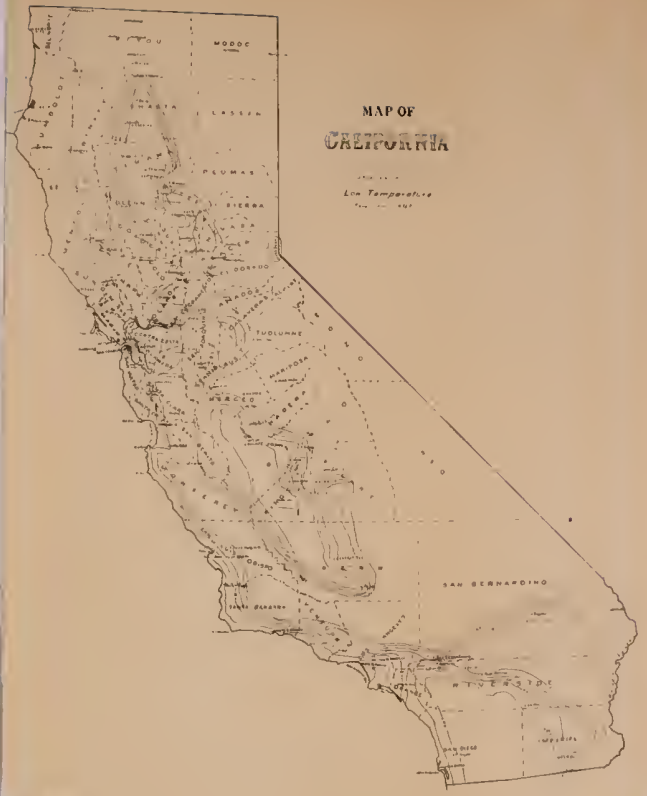




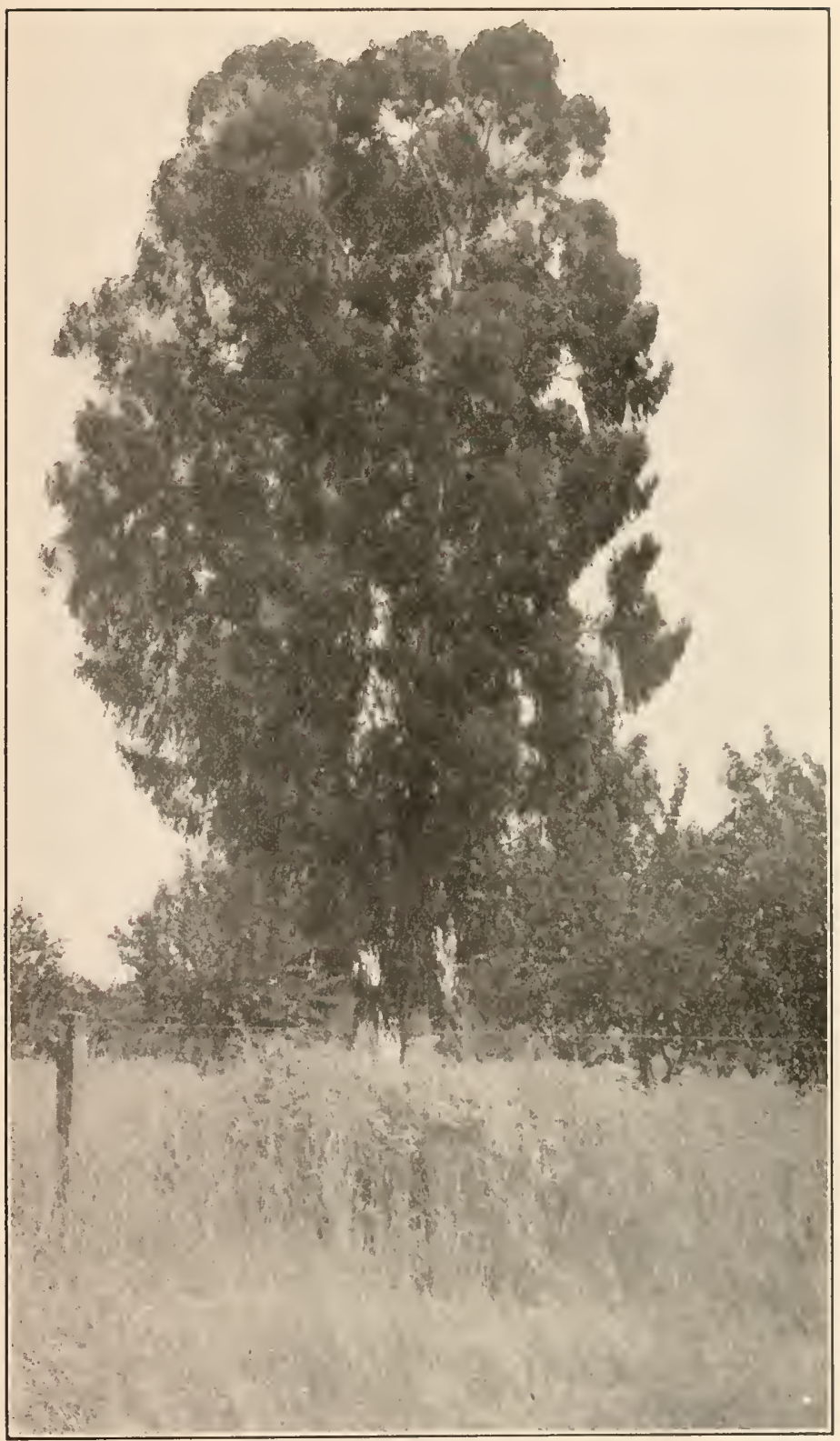

PLATE 3. Exceptional development of manna gum in the San Joaquin Valley. Trees clear, straight, and of very massive proportions. The two trees are 20 to 25 years old, 4 to 5 feet in diameter, 150 to 160 feet tall, and 50 to 60 feet clear. 
gum, but it is less frost-Iardy and produces a less durable though better formed timber.

HOML-GROWN

The following list contains the names and addresses of the California - firms that are known to deal in Encalyptus seeds and seedlings. Some of these deal in Euralyptus stork exclusively.

\section{Dealers in Eucalyutus sterd.}

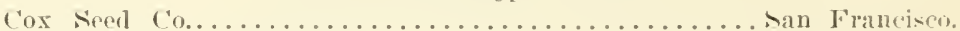

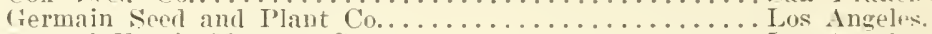

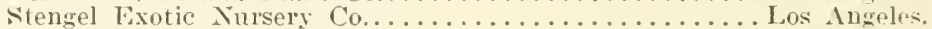

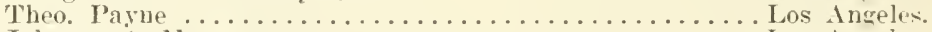

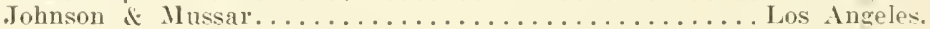

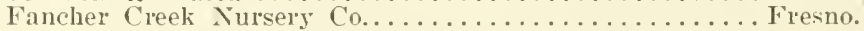

\section{Iurserymen Propagating Eurnlyptus SEedlings.}

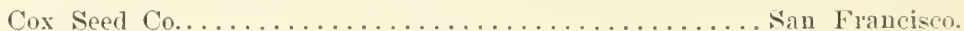

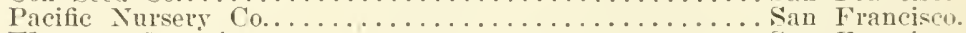

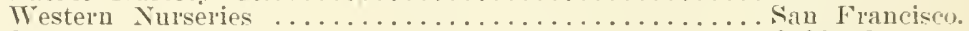

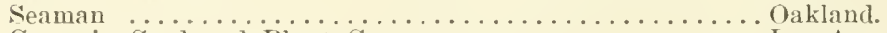

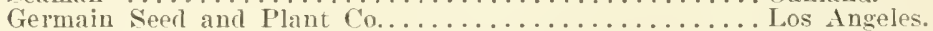

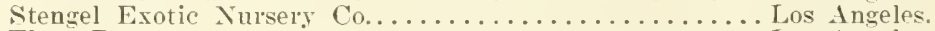

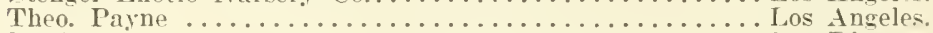

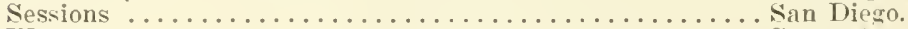

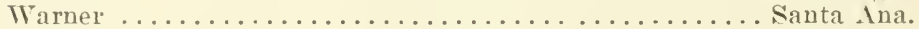

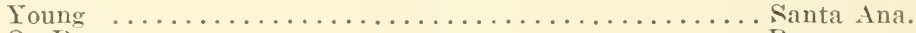

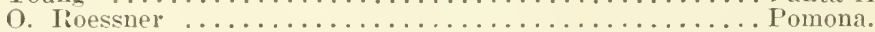

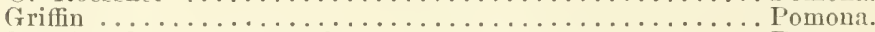

Fancher Creek Xursery Co................... Fresno.

Wilson .............................. Fresno.

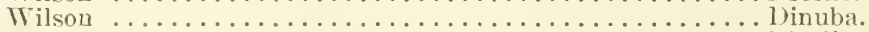

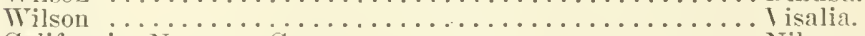

California Nurser.

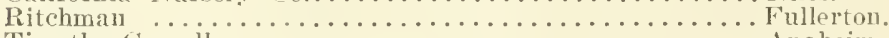

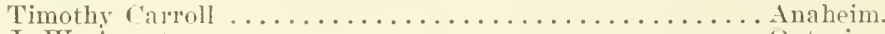

J. $\pi$. Armstrong. . . . . . . . . . . . . . . . . Ontario.

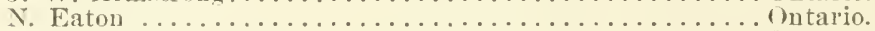

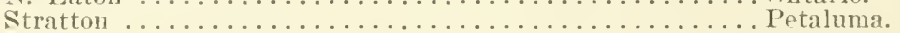

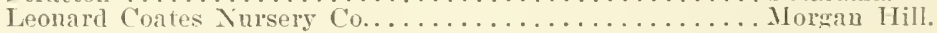

Whenever planters desire only small quantities of stock it will be advisable to secure it from a dealer. The price demanded for seedlings will be considerably higher than the actual cost of raising the seedlings. but not sufficiently great to warrant small planters attempting to propagate their own seedlings. Generally, the regular price will be reduced by a uurseryman even to a small planter who contracts in advance for a stated number of seedlings.

If large quantities of seedlings are to be used annmally for sereral consecutive rears. the saving in the cost of seedlings will warrant the planter in establishing a small nursery and propagatiug his own stock. The practicability of doing this depends largely on the local prices demanded for seedlings. however, and on the facilities at hand for raising them.

The prices for seedliugs exacted by nurserymen in different parts of the State vary from \$S to $\$ 30$ per thousand, depending largely on the local demand. Tence, if a planter lives in a locality where $\$ 30$ per. thousand is asked, it is expedient. at least, to use bome-grown seedlings. 
On the other hand, if but $\$ 8$ per thousand is demanded, generally, it will be more advisable to purchase them outright than to assume the initial expense of preparation and the subsequent work of propagating the plants, although they can be raised for $\$ 2.50$ to $\$ 3.50$ per thousand.

Cheapness is not the only quality which commends home-orown seedlings. The certainty of having them when they are wanted is assured. and generally higher-grade stock can be raised than nurserymen supply. The risk entailed in transporting seedlings from the nursery to the planting site is also avoided.

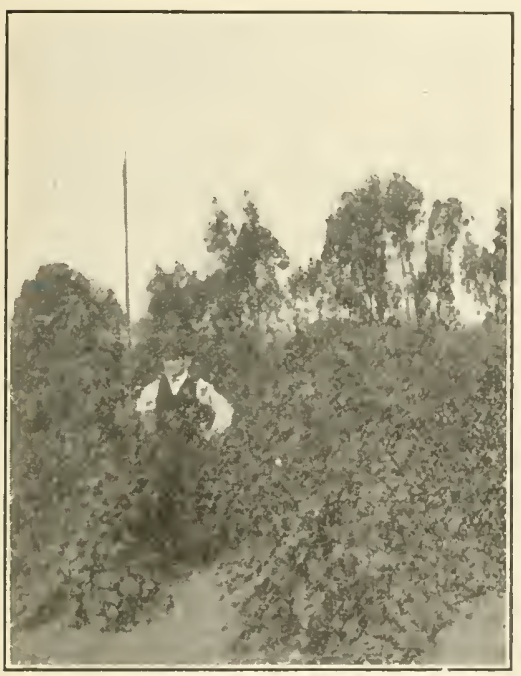

sugar gum plantation, 1 year old, in Los Angeles Valley. Trees now 6 feet tall.

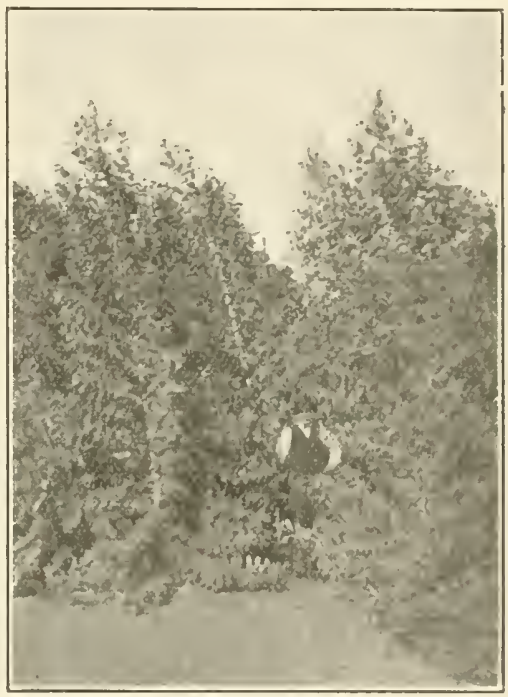

PLATE 4.

BIue gum plantation, 1 year old, in Los Angeles Valley. Trees now 14 feet tall.

NIURSERY PRACTICE.

Lath House. As stated muler the heading "Tolerance," Eucalyptus seedlings are naturally shade-demanding and sueceed best muder partial cover. This condition is created artificially by the ronstruction of a lath house, within which the seedlings are raised to planting size. The amount of light admitted is determined by the width of the spaces hetween the laths. In practice it has been found that half light and half shade, secured by spacing the laths a distance equal to their width. is about right.

It sometimes happens that the seedlings are attacked by a fungous disease called "damping off," which really amounts to the rotting of the stems just at the surface of the soil. This disease is particularly. liable to appear if the seedlings are watered too much, or in the late 
aftemoon whon the soil remains wet overnight, or when they are orer-shaded. T'o cherek it, it is necessary to admit more light or to sprinkle the surface of the seed boxes with dry sand. In any wase the admission of light and the freer circulation of air are desirable. hence the laths shomld be put on in panels so they can be removed if desirert.

Another point to be observed in constructing a lath house, particularly in windy locations, is to lay the lath on the sides of the house diagonally instead of rertically or horizontally. This will give the house greater strength.

The size of the house must be determined by the number of seedlings required per year. As a general guide it is safe to count on forty seedlings for every square foot of floor space enclosed.

Seed Boxes. It is desirable to sow Eucalyptus seeds in boxes instead of in the open soil, in order to farilitate the handling of seedlings and to control the derelopment of their roots. The boxes should be about 18 to 20 inches in surface dimension by 3 or 4 inches deep, and filled almost to the top with fire, mineral soil, free from weed seed. This should be smoothed uniformly, care being taken not to leave any hollows or holes, and not more than 1,000 seeds shonld be sown in each box. After sowing, the seed should be covered a little deeper than the diameter of the seed with a layer of fine sand.

After the seed is sown, a very light laver of leaf-mold, or sawdust. shonld be sprinkled on the surface of the soil. This will help to retain the mosisture and thus hasten germination. During warm weather germination may be expected in from four to ten days. When the seedlings appear above the surface the sawdust may be removed. Some contend that redwood sawdust prevents damping off. but the reason for this is not clear.

Watering steedlings. The legulation of the water supply for Euealyptus seedlings requires careful attention. Too much and too little water injures them equally. Nearly every diffienlty experienced in raising Encalyptus seedlings can be overeome by gauging the water supply so that the soil is kept moderately moist at all times during the sumny part of the day and somewhat drier at night. If the seedlings begin to wilt, they should be examined immediately and carefully to ascertain whether the wilting is due to drought or "damping off." for in the former case water is needed, while in the latter a drying process, already described. should be instituted. The symptoms are very similar and shonld not be confused.

As a general rule it is safer to err on the side of too little water rather than on that of too much. It shonld be given during the day when there is a considerable period of sunlight ahead. During the last two 
or three weeks before planting, the seedlings can be hardened and made more woody by curtailing their water supply, though it should not be withdrawn enough to stunt them.

Transplanting. If the 1,000 seeds planted in each box germinate and grow well they will begin to crowd each other when the seedlings are about two inches tall. When this condition obtains it should be relieved by pulling out all but 100, which should be left evenly distributed in each box. Those removed should be tramsplanted in other boxes.

In removing them from one box to another the roots of the seedlings should not be exposed to the air too long. Eucalyptus seedlings are not so tender as those of conifers, however, and will revive after considerable hardship.

Immediately after being transplanted the seedlings are likely to wilt slightly. If watered freely and shaded well for a few days, however, they will revive, unless the roots have been killed by exposure during the operation. To avoid this it is advisable to transplant on a cloudy or foggry day.

P'rotection of Nursery. The damage to nursery stock caused by birds and small rodents can be eontrolled by preventing them from effeeting an entrance to the lath house. Ants, however, are likely to invade the lath honse and eause considerable trouble if left inmolested. They can be kept from the seedlings by painting the edges of the boxes with corrosive sublimate, which the ants will not eross. An established colony ran be killed by pouring earbon bisulphid into the passage holes, which should then be plugged with dirt to confine the gas.

\section{FIELD PLANTING.}

In the portions of California snitable for Eucalyptus culture the season is divided between periods of drought and abundant rainfall. In some seetious the summer drought is broken by rains in October; in others it may continne till late in November or December, or even later. If late in January or in February sufficient rain has fallen to moisten the soil to a depth of one foot or more, planting should be begun in order that the plantation may become established during the continuance of the rainy season.

No fixed rules to govern planting need be given. Every planter can best decide for himself what arrangement of his men gives best results. On wild, uncultivable land it has frequently been found advantageous to divide the men into three squads. 'The first, consisting of men equipped with mattocks, preeedes the other and prepares holes for the seedlings by removing the sod and digging up the mineral soil. The 
second follows, each man having a box of plants and an ordinary trowel, which he uses to scoop out the loosened soil, making a hole to receive the plant, about the roots of which he packs soil closely. The third, consisting of less than half the number of either of the others, keeps the second squad supplied with plants. On tilled land the first squad may be dispensed with.

SPACING.

The proper spacing of secdlings in a plantation is a matter of first importance. Upon it depends the number of seedlings required per acre, the length of time cultivation is necessary, the rate of growth of the trees, and the character of the product. California planters, observing the small spindling trees in the interior of dense plantations and the larger trees along the edges, have inclined to very wide spacing. For different plantations the spacing has varied from 4 by 4 feet to 16 by 16 feet, and the opinion is prevalent that spacing 8 by 8 feet is too close. The very rapid growth of encalypts soon closes up an open plantation and seems to warrant wider spacing than is advisable with most slower-growing trees. For best results, however, Eucalyptus plantations should not be spaced closer than 6 by 6 feet, nor wider than 10 by 10 feet for any purpose.

The wider spaeing is allowable if firewood is the only product sought. For ties, piles. poles, dimension stuff, or any material in which good form is an indispensable quality, the plantations should be spaced not wider than 8 by 8 feet. Sugar and lemon gums, which naturally grow tall and spindling with scanty foliage, should be spaced 6 by 6 feet preferably, and never more than 8 by 8 feet. A similar spacing is recommended to correct the crooked-growing tendency of red gum.

Uniformity of spacing should always be attempted. Sometimes the topography of the planting area will render its attainment impossible, or at least impracticable, in which case it should be approached.

Level, tilled land can be marked to insure uniformity of spacing. On untilled land unifornity may be approximated by keeping the men in the mattock squad in line. Where extensive planting operations are carried on one man may be detailed to set flags at stepped distances apart, to guide the mattock men on the ends of the line. Those between them will soon learn to keep an equal distance apart.

\section{CULTIVATION.}

Wherever the condition of the planting area lends itself readily to cultivation, this treatment should be accorded the plantation at least two or three times during each of the first two dry seasons after planting. Once a month is better. Plantations on untilled land will respond sufficiently to hoeing to warrant its practice once, at least. 

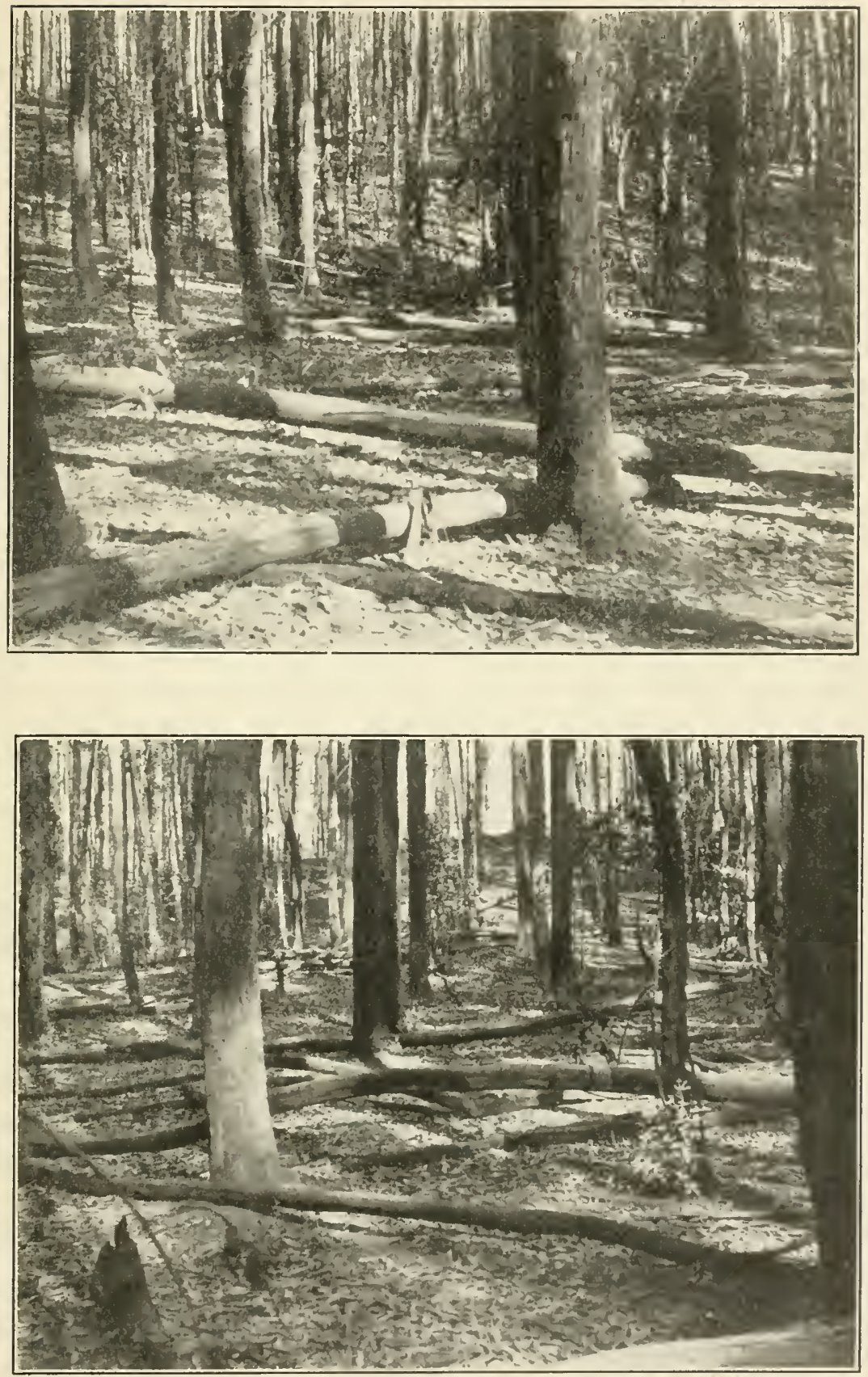

PLATE 5. Result of a severe ground fire in an old Eucalyptus stand. Trunks charred, many trees killed and fallen. the ground burned clear of litter, and now sprinkled with leaves from fire-injured trees. 
Too great stress can not be laid on the benefits derivable from cultivation. Not only is the weed growth, detrimental to plantations, destroyed, but the surface soil is loosened and evaporation is checked. 'The planter who attends carefully to the cultivation of his grove will be rewarded by the greater number of trees which withstand the drought and by the more rapid growth of his plantation.

COST OF PLANTATIONS.

The total cost of establishing and caring for plantations during the first two years has varied from $\$ 15$ to over $\$ 50$ per acre. An expense of $\$ 25$ per acre is generally considered a fair figure. However, this cost is the result of setting out small groves, for whieh seedlings have generally been purchased from nurserymen. When stock is grown in a home nursery the cost of planting large areas should not exceed $\$ 15$ or $\$ 20$ per acre. Small groves for which plant material is purchased will generally entail a higher expense.

\section{PROTECTION.}

Once the plantation is well established its protection from fire and roving stock is the chief feature of management to demand attention. Eucalypts are particularly inflammable, because of the oil contained in their foliage and bark, hence even a slow fire causes serious injury.

Plantations established in open country should have a strip fully a rod wide plowed around them every spring, particularly if they are situated near a railroad or in a locality frequented by hunters. In addition, the owner or caretaker of the plantation should secure an appointment as fire warden from the State Forester, and obtain a supply of fire-warning notices to post conspicuously in the vicinity of the plantation. Although the danger from fire is great in many portions of the State, planters should not be deterred by it, for they have full redress for damages through a civil action, whenever sufficient evidence of the careless or malicious origin of the fire can be collected.

Roving stock of all kinds should be strictly excluded from the plantations. The need for this is particularly great while the trees are small enough to be trampled upon.

Gophers, squirrels, rabbits and other rodents which infest and damage roung plantations should be destroyed by firearms or poison.

\section{CUTTING, THINNING AND PRUNING.}

All operations which curtail the foliage of the tree should be performed during the late fall or winter, when its functioning processes are suspended or least active. If this is done the surface cut will heal 
during the time the tree is dormant and loss of vitality by "bleeding" will be avoided.

In eutting, care should be exercised to slope the stump like the roof of a house, so that the rain falling on it will be conducted off instead of sinking in and permitting fungous growth to start. It is also advisable to eut the stumps very low the first time, for succeeding cuttings will have to be higher to avoid the thickened growth caused by the production of numerous coppice shoots.

The advisability of thinning depends on the age which the grove will be allowed to attain and the use to which the product is to be put. If the grove is to be cut for firewood when six or seren years old, thinning will not be advisable. But if the plantation is expected to produce telephone or telegraph poles, piles or dimension material, which will require longer to mature, a moderate thinning will be advisable during the winter of the fifth or sixth year after the trees have been forced into height by crowding. As soon as the competition for light is relieved by thinning, the rate of height growth will deerease and that of diameter will increase.

The degree of thinning must always be determined by the condition of the plantation and the character of the product desired. Groves should never be opened enough to permit the growth of weeds or to allow the slender trees to be thrown by the winds. Definite rules can not be given in advance. Unless the planter has had experience enough to guide his judgment, it will be advisable to secure an examination of the plantation by a forester, which may be done under the conditions of Section 4 of the State Forest Law.

Pruning will be inadvisable generally. If the plantations are spared properly the formation of objectionable branches will he prevented hy lack of light.

\section{GROIYTH.}

The measurements upon which the accompanying tables of wrowth and yield are based were taken in different groves npon sample plots aggregating approximately 10 per cent of the total alea of Eucalyptus plantations in California. Since blue gmm has been planted commercially to the exclusion of other encalypts. the collection of data was necessarily restricted to plantations of this speries. Althongh the growth of blue gum is the most rapid of the emalypts planted in california, the tables may be used to estimate the growth of other rommercial species.

The portions of the State for which the tables maly be regarded as anthoritative are: the Bay comnties, the coast region noul Sinta Barhara. the Los Angeles and Santa Ana valleys, and the voastal valleys near 
San Dicyo. 'The localities in which the groves measmred are situater are mentioned in tables 4 to 10 . No plantations are growing in other sections of the State from which data upon growth and yield ean be ohtained, but the tables will undoubtedly indieate elosely the growth of blue gum thronghout its planting range.

The majority of the groves measured were situated in Sonthern California, and the data were eollected after the suecession of exceptionally dry years in that section from 1898 to 1903 . The growth of plantations was eonsiderably retarded during that period of very low rainfall, the sites, oceupied by the groves giving the lowest yield, being generally those most unfavorably affected by the drought. The majority of the groves when measured were less than eight years old, hence their growth does not represent the maximum productive eapacity of their sites. It is believed the tables are very conservative for the growth of blue gum in California.

Tables 1 to 3 show the volumes of blue gum trees in eubie feet, cords and board feet. For these tables measurements of seedlings and sprout trees were combined, since they differ but little in form and habit of growth. The cubic foot and eordwood tables are based on the computation of the contents of entire trees. The volume and the clear length only, sealed by the Scribner rule, was used for the board foot table. Owing to the seareity of plantations of older and larger trees, volumes can not be given for trees over 160 feet in height, 24 inehes in diameter, and 30 years of age.

In both the volume and yield tables for cordwood, the New England cord of 128 cubie feet is used. The results were obtained by dividing the figures given in the cubic foot tables by 90 cubie feet, which represents very closely the average solid contents of a cord of Eucalyptus wood. However, the New England cord is little used in California, a cord of 96 eubic feet, or about 65 eubic feet solid eontents being in general favor. To ehange from New England to California eords, the amounts should be inereased one-fourth.

Tables from 4 to 10 record the growth and yield of individual blue gum plantations. Separate tables have been construeted for seedling and sprout plantations upon different types of soils. Portions of many sprout groves have been cut at different periods, and represent the growth at different ages. Therefore, different portions of the same groves are often separated in the tables to permit arrangement of the sample plots by successive ages, and to show the progress of growth and yield.

In the spront yield tables the number of trees in the column showing the present stand per acre is often several times as great as would lesult from the spacing mentioned. This is due to the number of 
sprouts allowed to yrow up from a stump after cutting the seedling tree. In the seedling table the number of trees in the present stand is frequently lower than the spacing would indicate. This results from the thinning or burning of the stand or the natural reduction in the number of trees. If a stand has been thinned or burned, the fact is noted in the column headed "Remarks."

TABLE 1.-Volume of Blue Gum Seedlings and Sprouts.

\begin{tabular}{|c|c|c|c|c|c|c|c|c|c|c|c|c|c|c|}
\hline \multirow{2}{*}{$\begin{array}{l}\text { Diameter } \\
\text { breast- } \\
\text { high. }\end{array}$} & \multicolumn{14}{|c|}{ Total height-Feet. } \\
\hline & 30 & 40 & 50 & 60 & 70 & 80 & 90 & 100 & 110 & 120 & 130 & 140 & 150 & 160 \\
\hline \begin{tabular}{l}
\multicolumn{2}{r}{ Inches. } \\
2 \\
2 \\
3 \\
4
\end{tabular} & $\begin{array}{r}0.4 \\
.6 \\
1.0 \\
1.6 \\
\end{array}$ & $\begin{array}{r}0.7 \\
.9 \\
1.4 \\
2.1 \\
3.0 \\
0 .\end{array}$ & $\begin{array}{l}1.0 \\
1.3 \\
1.9 \\
2.6 \\
3.6 \\
4.8 \\
--.-\end{array}$ & $\begin{array}{l}1.3 \\
1.7 \\
2.3 \\
3.2 \\
4.3 \\
5.7 \\
7.3 \\
9.0 \\
-. .\end{array}$ & $\begin{array}{r}2.8 \\
3.9 \\
5.2 \\
6.8 \\
8.6 \\
10.7 \\
\\
\end{array}$ & $\begin{array}{r}3.3 \\
4.8 \\
6.4 \\
8.1 \\
10.1 \\
12.4 \\
15.0 \\
17.6 \\
20.4 \\
23.7 \\
\end{array}$ & $\begin{array}{r}r \text { eme- } \\
5.8 \\
7.6 \\
9.6 \\
11.8 \\
14.4 \\
17.2 \\
20.4 \\
23.7 \\
27.2 \\
\end{array}$ & $\begin{array}{r}\text { Cubic } \\
9.0 \\
11.0 \\
13.5 \\
16.4 \\
19.6 \\
23.0 \\
26.6 \\
30.7\end{array}$ & $\begin{array}{r}15.4 \\
18.6 \\
22.1 \\
26.0 \\
30.9 \\
34.4 \\
39.2 \\
\end{array}$ & $\begin{array}{l}20.5 \\
24.7 \\
23.1 \\
33.5 \\
38.0 \\
42.3 \\
46.5 \\
50.9 \\
55.0 \\
-\end{array}$ & $\begin{array}{l}27.3 \\
32.0 \\
36.8 \\
41.5 \\
46.3 \\
51.2 \\
56.0 \\
60.8 \\
65.8 \\
70.7\end{array}$ & $\begin{array}{l}45.7 \\
51.3 \\
56.8 \\
62.5 \\
68.4 \\
74.2 \\
80.0 \\
86.0 \\
\end{array}$ & $\begin{array}{r}71.6 \\
78.3 \\
84.9 \\
91.5 \\
98.6 \\
105.8 \\
112.8 \\
120.0\end{array}$ & $\begin{array}{r} \\
\\
\\
\\
\\
91.2 \\
98.0 \\
105.0 \\
112.5 \\
120.0 \\
127.5 \\
135.0\end{array}$ \\
\hline
\end{tabular}


TABLE 2.-Volume of Blue Gum Seedlings and Sprouts.

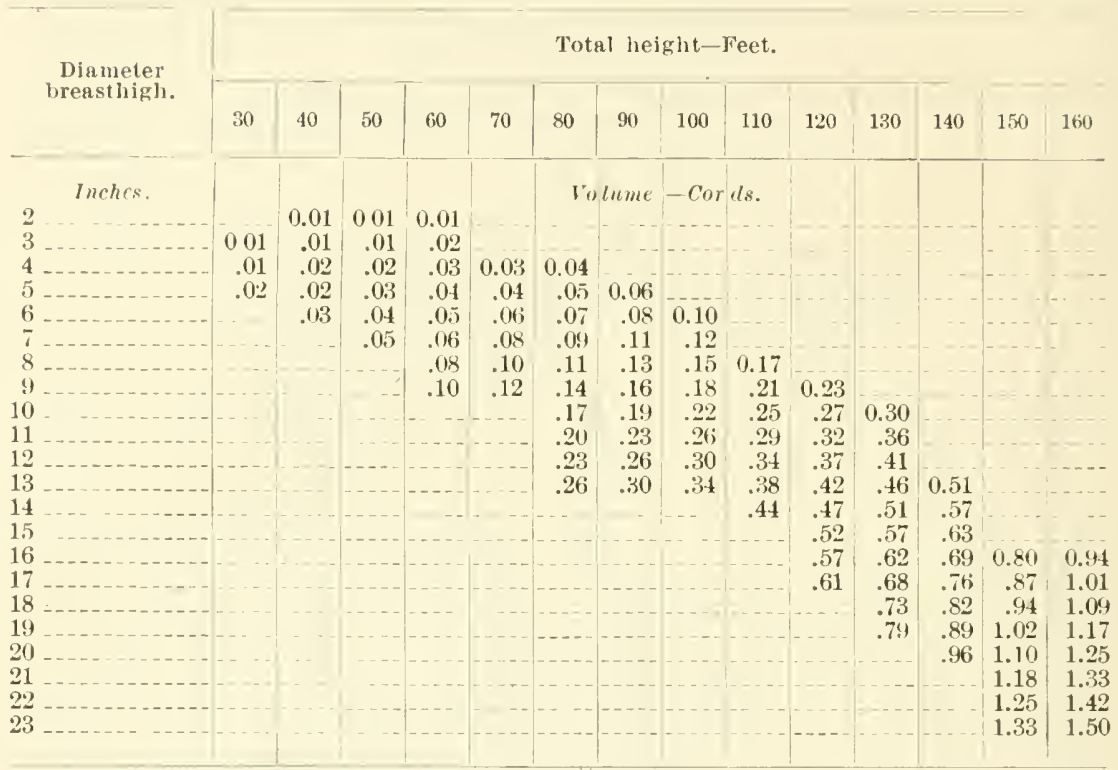

TABLE 3.-Volume of Blue Gum Seedlings and Sprouts.

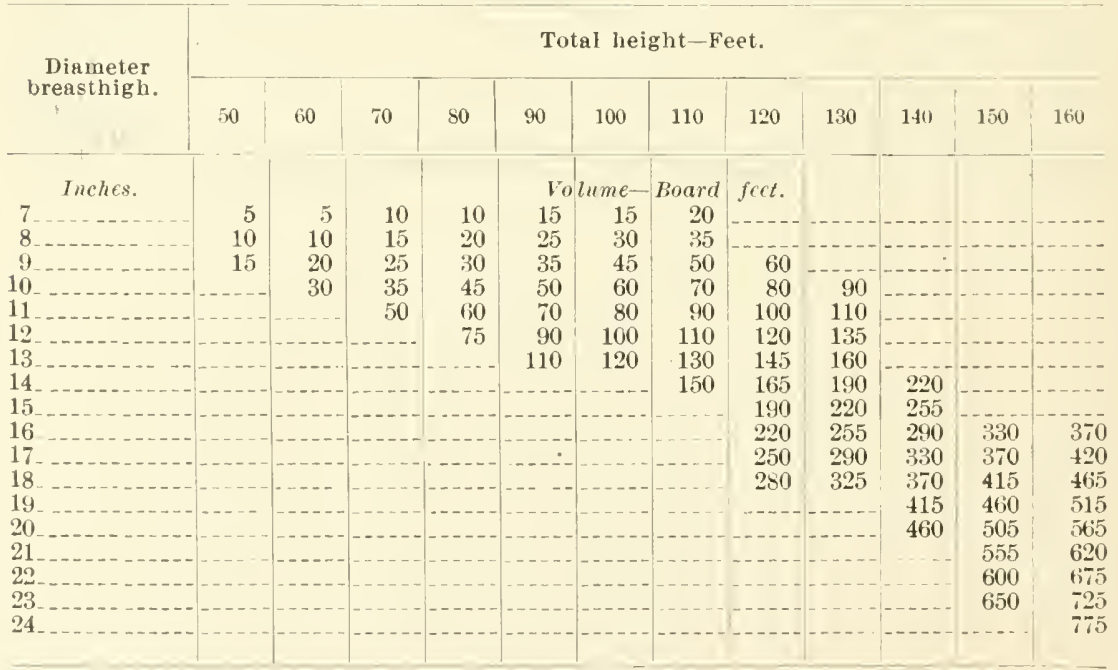




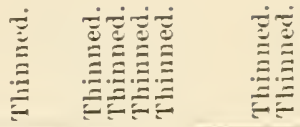

| 立 至

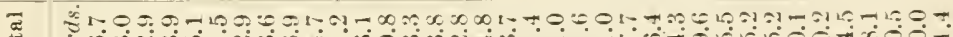

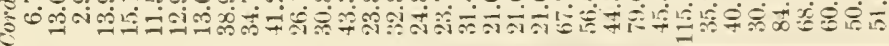

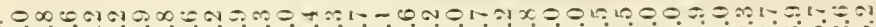
-

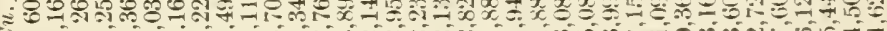

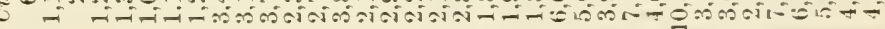

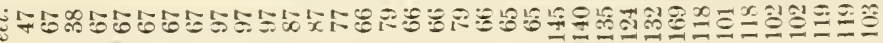

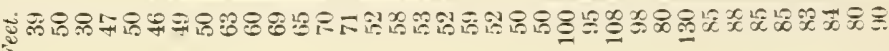
2

ใิำ

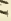

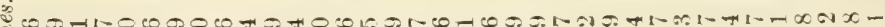

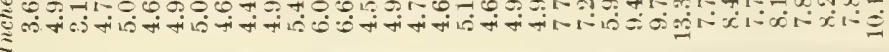

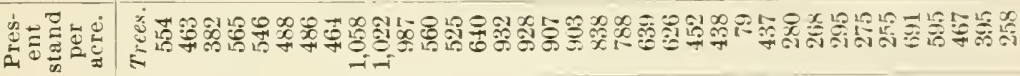

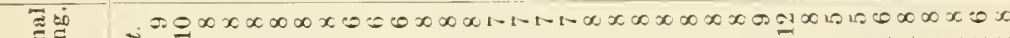
E

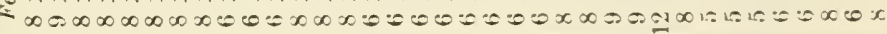
药

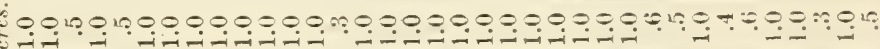

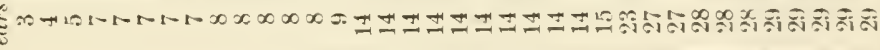

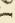

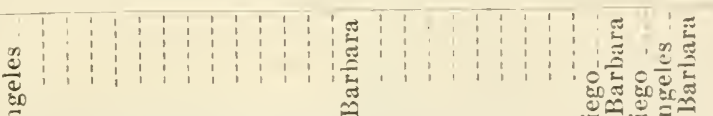

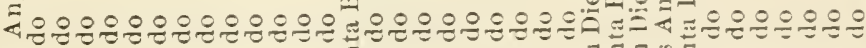
点 


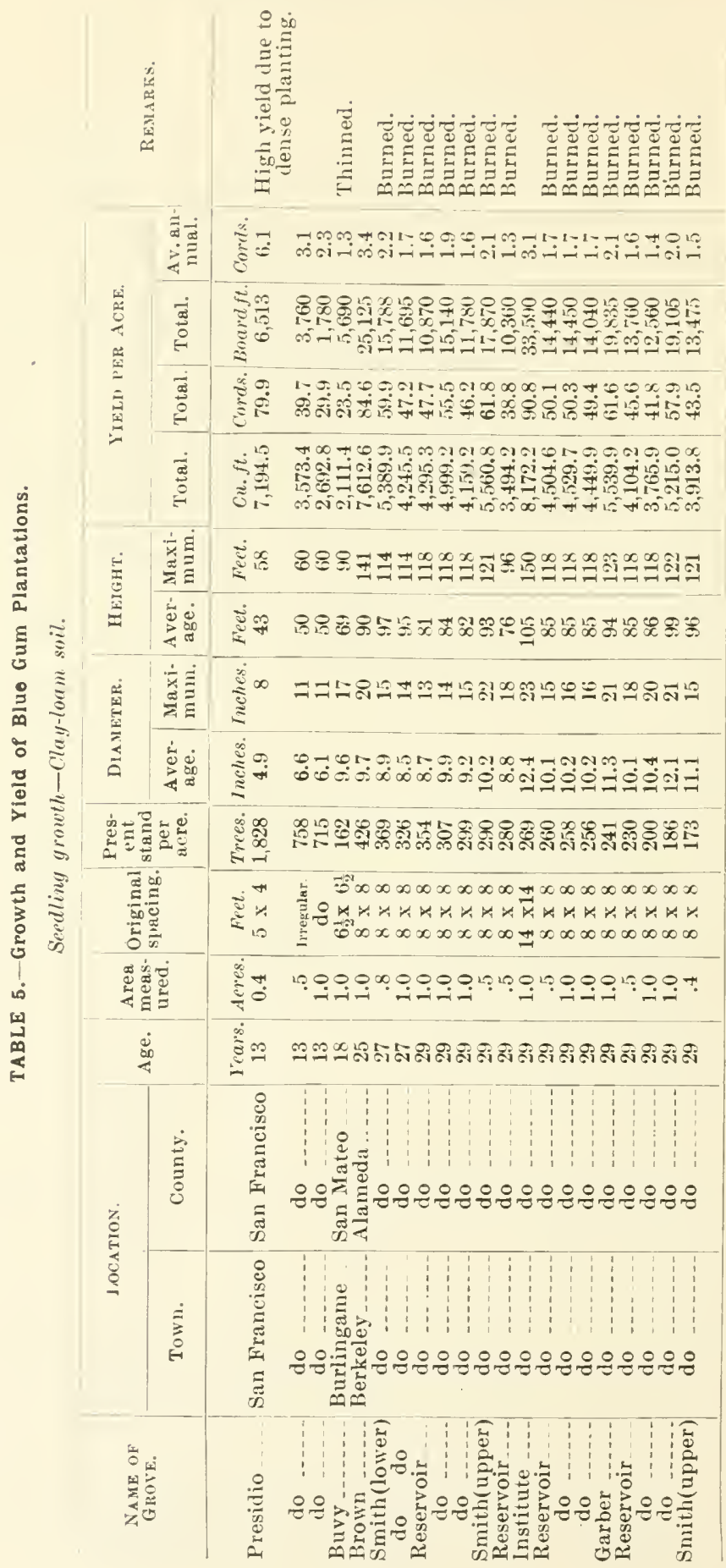


A HANDBOOK FOR EUCALYPTUS PLANTERS.

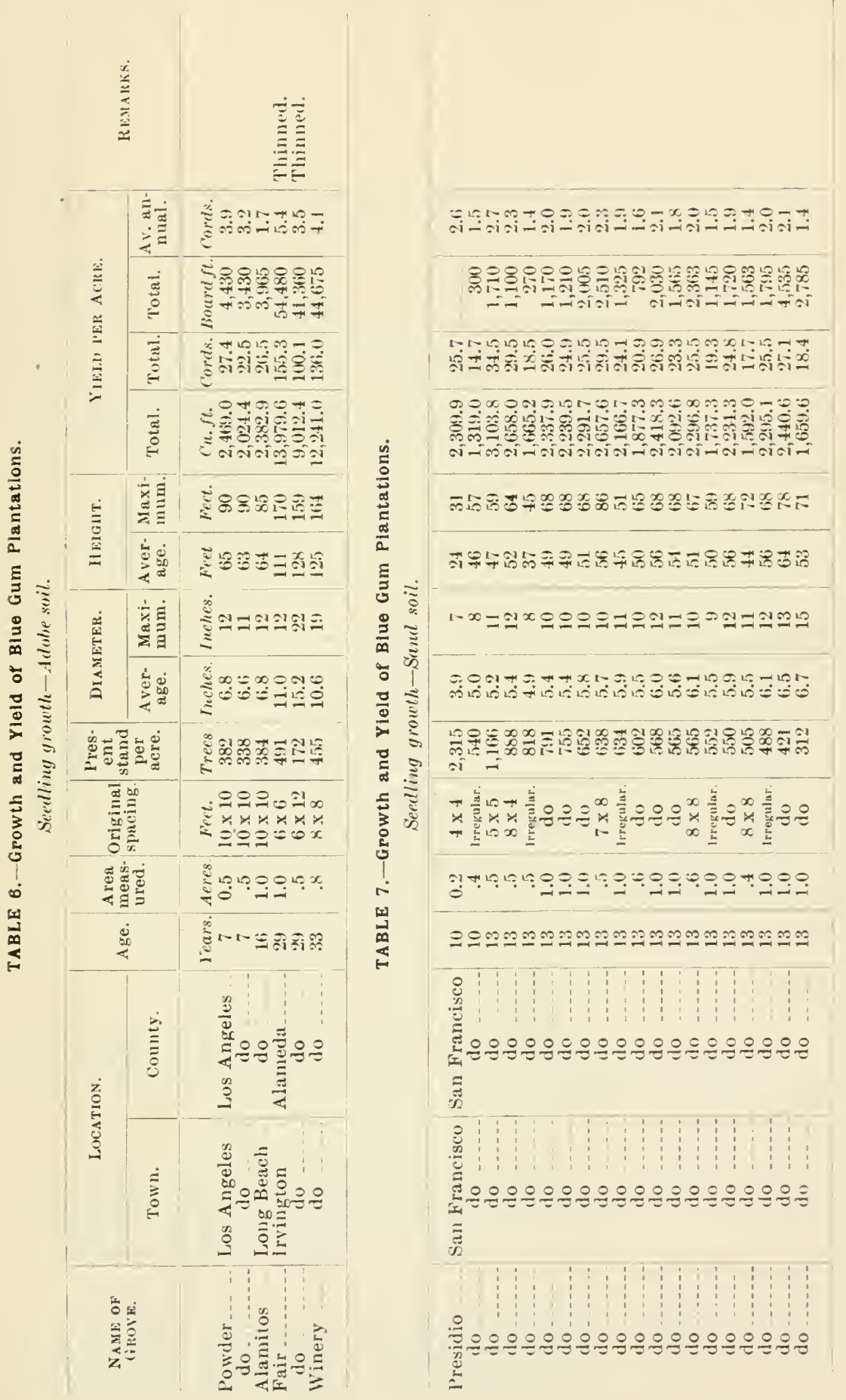




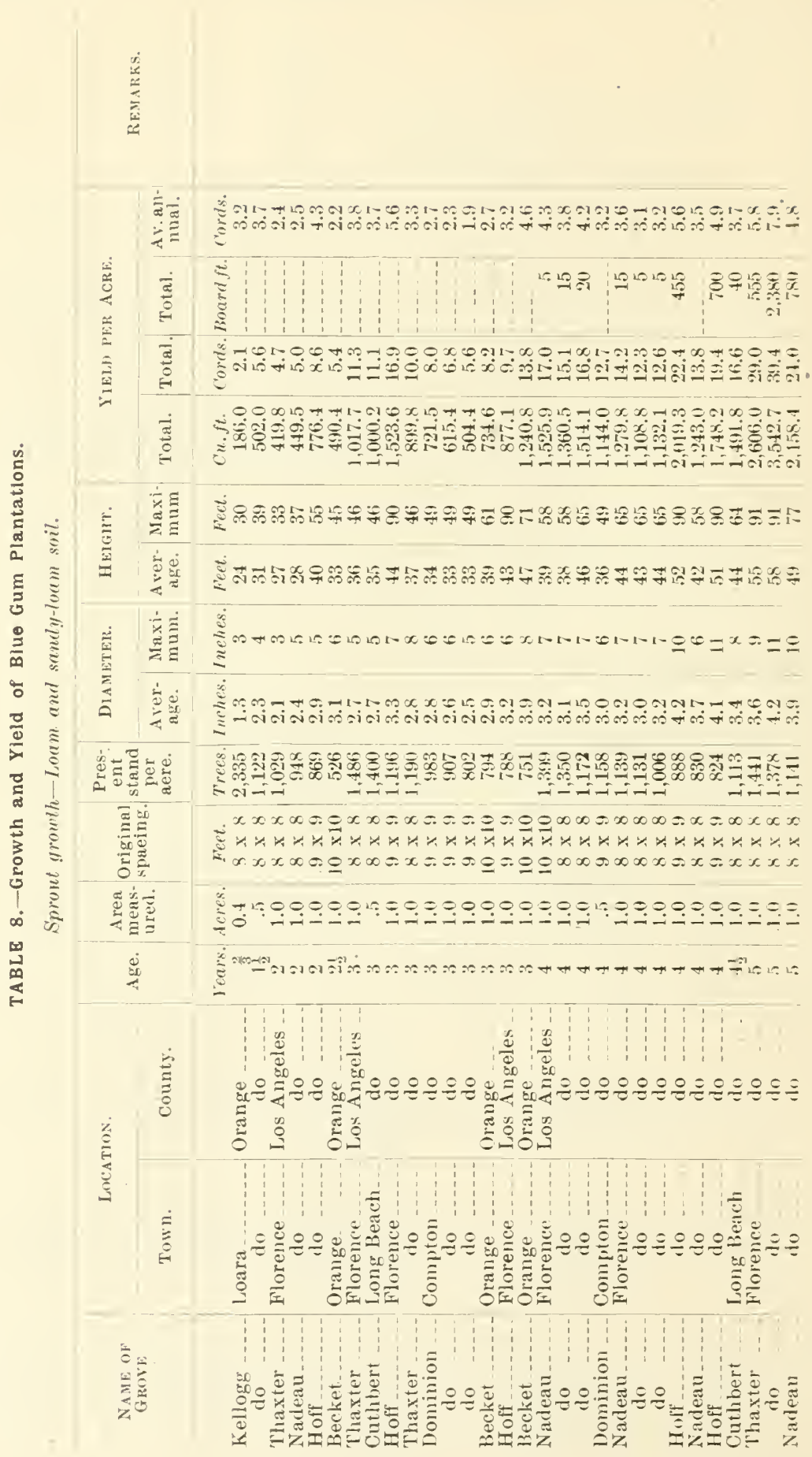




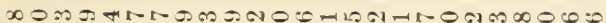

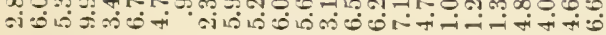

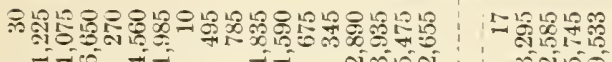

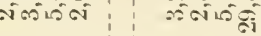

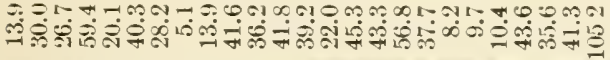
TL L

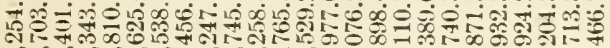
-

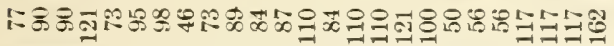

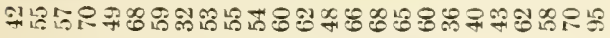

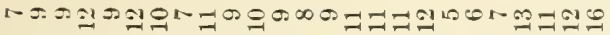

7.

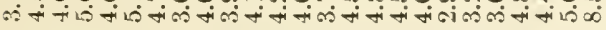

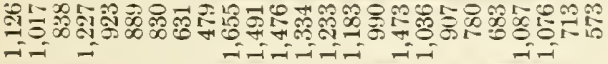

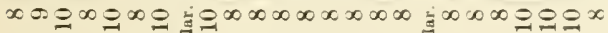

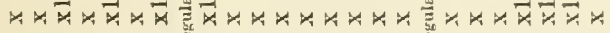

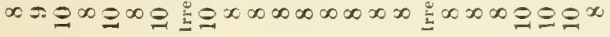

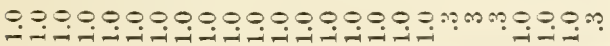

LO L L L

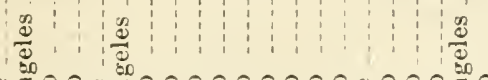

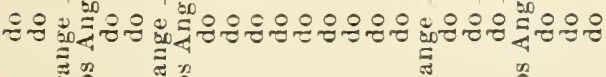

象

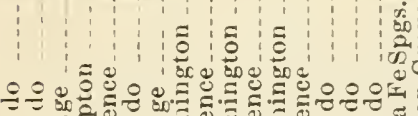

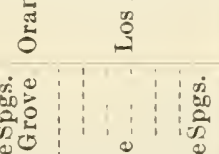

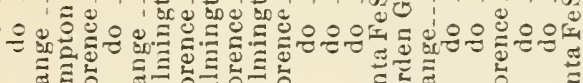

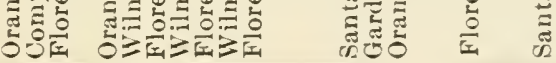

(1) 
A HANDBOOK FOR ELCALYPTUS PLANTERS.

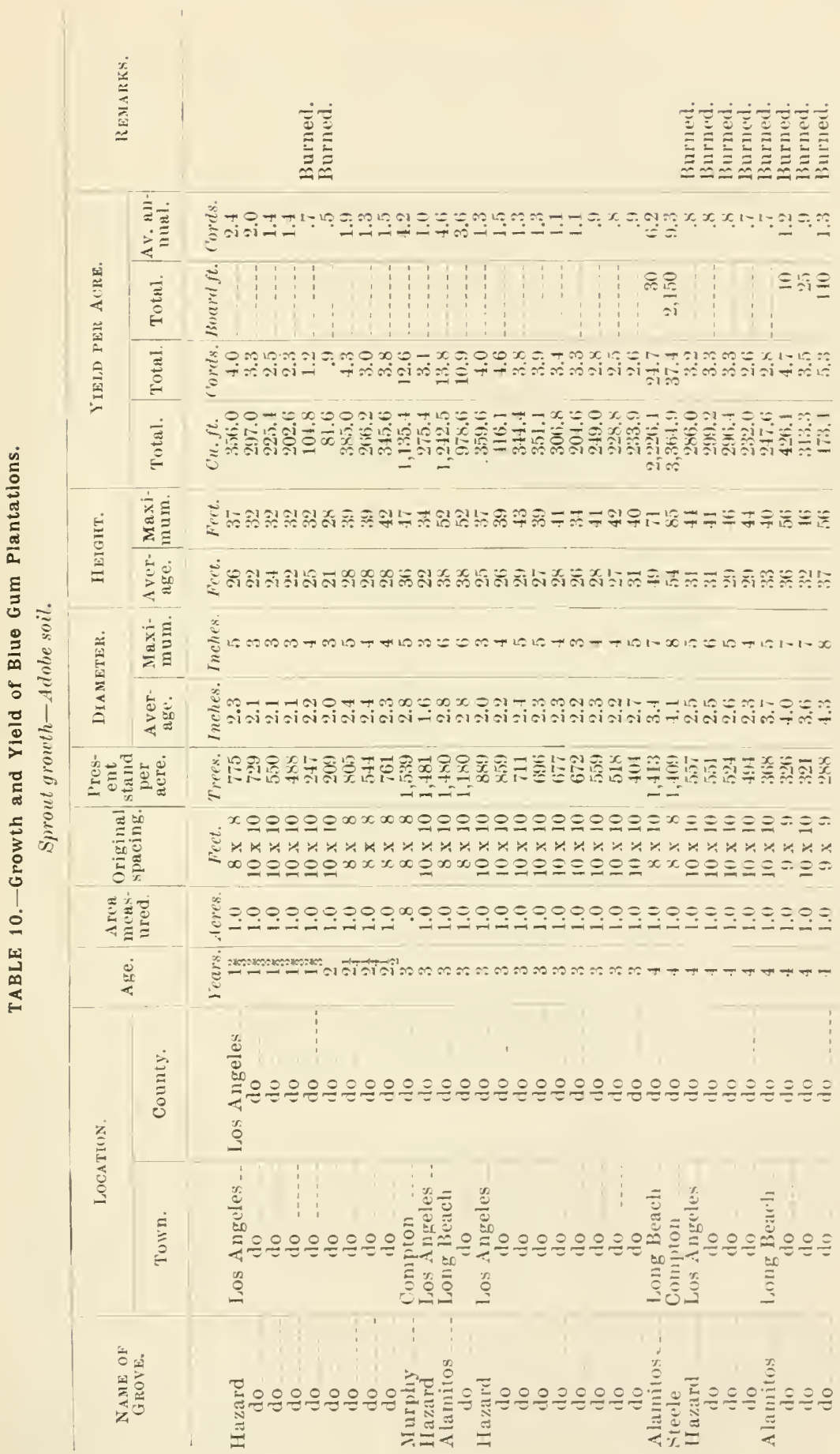




\begin{tabular}{|c|c|c|}
\hline \multirow{4}{*}{ 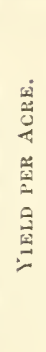 } & 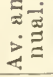 & 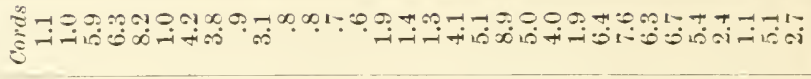 \\
\hline & 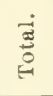 & : 1 \\
\hline & $\stackrel{\vec{a}}{\stackrel{\Xi}{0}}$ & 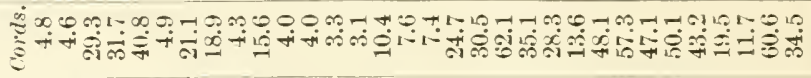 \\
\hline & 莣 & 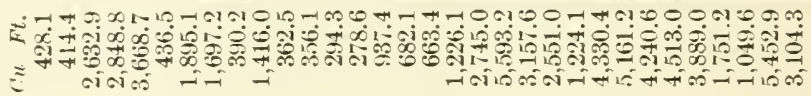 \\
\hline
\end{tabular}

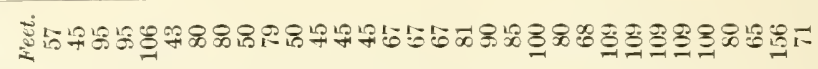

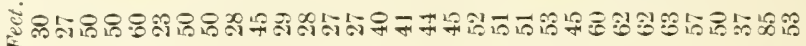
苛

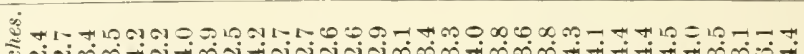

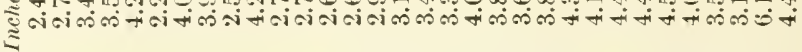

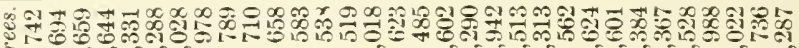

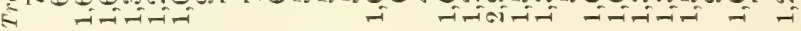

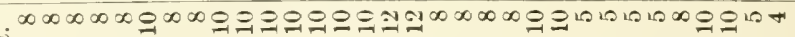
岕

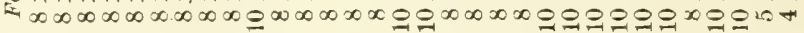

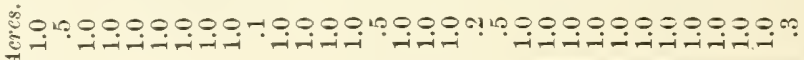

$\frac{2}{2}$ 00000000000000000000000000000000

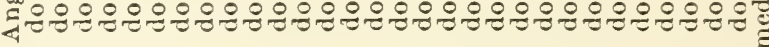

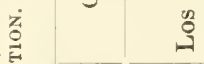
$\frac{\mathrm{E}}{4}$

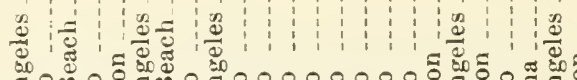
过 \&

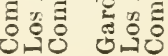

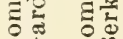

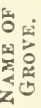
式 
The blue gum has gained the reputation of possessing a phenomenal rate of growth, and by an inspection of the figures of average and maximum growth this may be appreciated. Under favorable conditions trees in seedling plantations have reached a maximum development of 5 inches in diameter and 67 feet in height in four years. This represents an average of 17 feet height growth per year, thongh a growth of 10 to 15 feet in height yearly is the goneral average. In the height of the first growing season seedlings have frequently been observed to make an average height growth of 6 inches a day. The most rapid seedling growth noted was made by a tree which in nine years reached a height of 125 feet and a diameter of 36 inches. As is usual among vigorously sprouting trees, sprouts upon old root systems surpass seedlings in rate of growth. Ages are occasionally recorded in the sprout tables in fractious of a year, representing the number of months' growth. In eight months a maximum diameter of 3 inches and 34 feet height has been reached while in three year's a maximum diameter of 7 inches and 70 feet in height has been attained.

In different groves and even upon different sample plots in the same grove a considerable variation in yield is shown, often ranging from maximum to minimum upon the same soil. This variation is determined to some extent by the character of the planting site, the permeability of the soil and the moisture available, and partly by the density of planting. It is governed mainly, however, by the density of the present stand of trees in consequence of the treatment accorded after planting. The deterioration of a grove because of lack of cultivation or protection, or from neglect after cutting. is sufficient to reduce the vield to a minimum on sites capable of maximum production. Unfortunately, the variation of this factor prevents its use in the construction of tables.

Sufficient data are not available from the measurements of roung plantations to construct a complete table, giving the yield of poles and piles at different ages. A tree with a butt diameter of 9 inches is required to produce a pole of the smallest merchantable size, namely, 20 feet long with a top dianeter of 7 inches. Spront stands are usually cut before eight years of age, and in this time the yield of poles is low, since few trees in dense sprout stands attain the butt diameter required. The acre yield of poles having a top diameter of 7 inches from two representative seedling plantations of maximum growth has been estimated as follows:

TABLE 11.-Yleld of Poles per Acre.

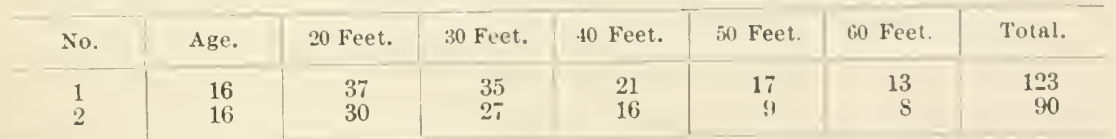

Each of these acres yielded, in addition, 30 cords of fuelwood.

3 - BF. 


\section{ECONOMIC PLANTING.}

Windbralis. The protection afforded by windbreaks must be reckoned an important factor in the horticultural development of California. The necessity of windbreak protertion in many sections of the State is so great that withont it certain crops can not be raised. Many trees are suitable for windbreak planting, yet California farmers are uniteri in the opinion that Monterey eypress is the only competitor of blue gum and other encalypts for this purpose.

The encalypts excel other species in their towering height and rapid growth. thus affording a protection most quickly. The trees are slender and open-crowned, but double rows of trees or close planting provide a strong check against the wind. The blue gum surpasses all others for this purpose, and should be used throughout its thermal range. Its tall, limber shafts vield before the wind and act as a cushion to deflect the air currents upward over an orchard, while ordinary windbreak trees form a solid wall on the leeward side of which the wind draws down and forms eddies.

In the open valleys of Southern California Eucalyptus windbreals have become a prominent feature of the landscape and their presence is recognized as indispensable to successful orcharding. To their protection may be attributed in large measure the fine quality of the California citrus crop, and in this way these trees return vast sums amnually to the State. In citrus sections, such as the Santa Paula, San Fermando. San Bernardino, San Gabriel and Santa Ana valleys, windbreaks alone render the production of citrus fruits profitable. In unprotected orchards, nearly the entire crop is frequently blown from the trees. or so scarred and bruised that the grade and market value are much reduced. Orchard trees are even broken or partially defoliated during. severe storms. To avert this danger and improve the grade of fruits. windbreak planting is being greatly extended even in old citrus sections.

More extensive shelter-planting is advisable in many sections of the State, notably in the Sacramento and San Joaquin vallers. Hitherto windbreaks have been used chiefly to shelter citrus orchards. bnt now they are coming into favor to shelter vinerards, deciduous orchards. olives and walnuts. Much more extensive development may be attained by their use in sections where strong or cold winds are felt. Along the coast, shelter from sea winds is found to increase the rield of grain (rops.

Eucalyptus windbreaks in some sections have changed the aspect of the country and by moderating the winds have greatly improved the climate. Waste. sandr, stretches have been turned to productive agricultural use. In the region of Oxnard the towering windbreak lines hold the loose sand from drifting before the steady sea winds. and 
the region has thus become. largely through their agency. an important renter of sugar-beet proulnction.

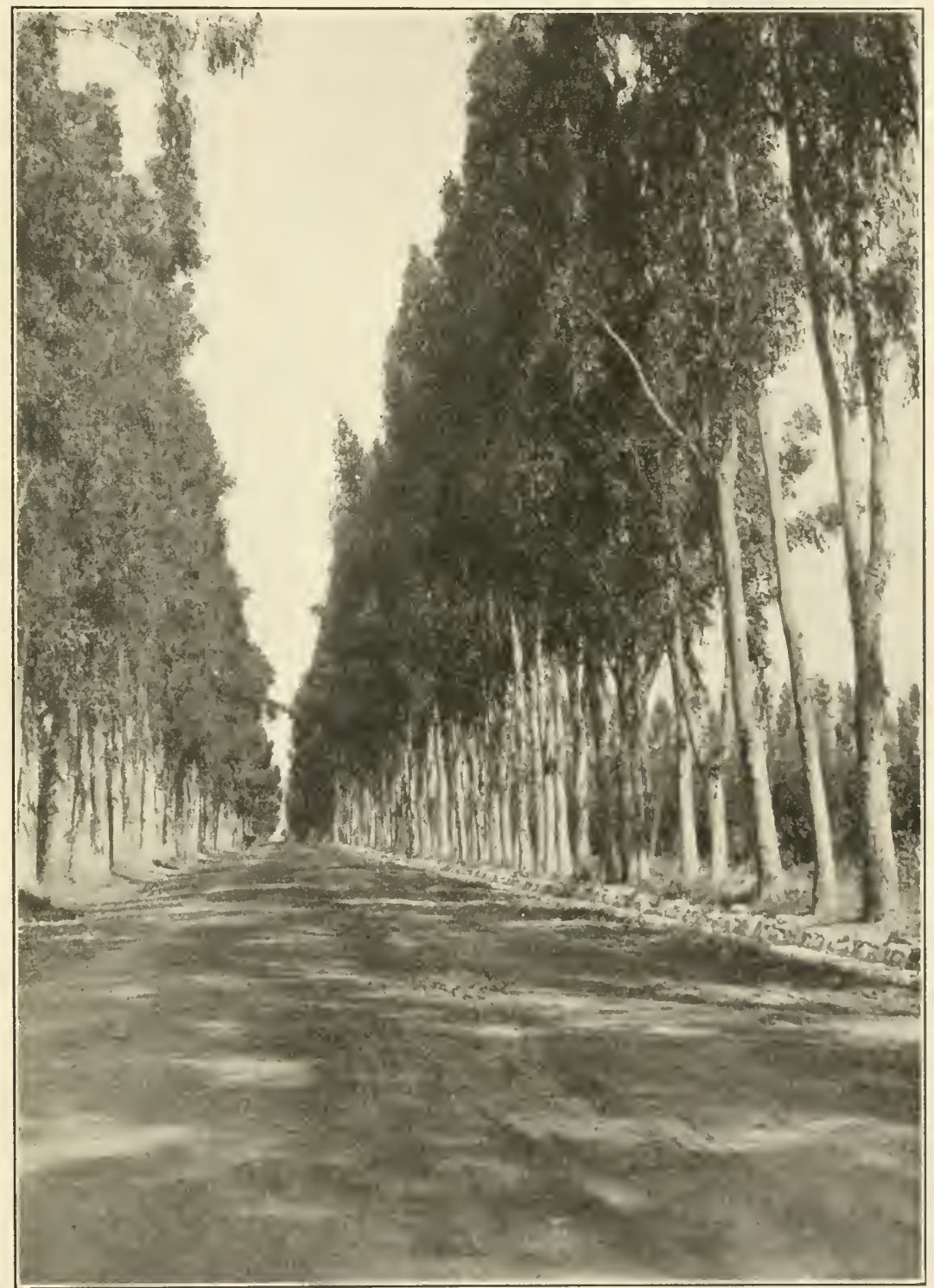

PLATE 6. Avenue planted with blue gum trees in San Bornardino Valley. Trens serve as windbreaks for citrus orchards. Thry are 12 to 20 inches in diameter and 125 feet high at 12 to 15 years of agr.

Along the east the planting of shelter belts for the protection of fowns has been practiced to some extent, to the greater comfort of the 
resident popmlation. 'T'his branch of shelter planting should be extended marticularly on the windward side of seaport towns, where windbreaks in proper places will protert anchored vessels and facilitate shipping. Windhreak planting should also be practiced in many coast localities to hold the sand from drifting inland and rovering up valuable agricultural land, crops and dwellings.

Fully grown Enealyptus windbreaks running at right angles to the direction of the prevailing winds every quarter mile across level country afford effective protection. Near the foothills the lines should be closer together, since the winds blowing down from the mountains gain greater velocity. Through orchards they are gencrally located every 100 or 200 feet. Thongh a heavy wind may be swaying the tops of the trees in a windbreak, usually there is hardly any stir in the air near the ground within a well-protected citrus orchard. The wind is never sufficiently strong to whip the foliage or injure the fruit.

All crops protected in this way suffer less from winds than opengrown crops. They remain uninjured when unprotected crops are blighted, unless the arrangement of the windbreaks results in defective wind-drainage and the formation of a frost hole. After a cold night. during frosty winter months, the shade cast by a windbreak on the eastern side of an orchard will often prevent injury from too rapid thawing.

Citrus trees are unfavorably affected by shade, hence the yield of fruit of rows adjoining a windbreak is often lessened. Windbreaks on the north and east sides of an orchard are less harmful than on the west or south side. Under ordinary conditions the south side of an orchard should be left open for wind-drainage.

The best spacing of gum trees for windbreaks is 4 feet apart each way in double rows. The trees of the second row should be planted opposite the open spaces in the first row. Double, or even triple, rows should be planted where the winds are severe. Triple rows will always be adequate for crop protection, though shelter belts from 10 to 20 rows wide may be advisahle to protect from strong sea winds.

Monterey cypress is frequently planted alternately or in double rows with eucalypts to maintain a dense shelter near the ground, since the gum trees clear the lower stem with later growth. giving access to the winds. This combination is an excellent one, since great density is united with towering height. The cypress is well adapted to this use by its tolerance of shade. Cypress and encalypts should be planted in separate rows and not alternated in the same row, the cypress being located on the windward side of the line, excepting on the north side of a field, where it should be planted on the south side of the line to receive more light. 
On irrigated land trees are not compelled to root deeply for moisture. hence they maintain a very shallow root system. If a Eucalyptus windbreak surrounding irrigated land is not irrigated, its roots will extend to adjoining orchards and appropriate moisture from them to supply its own needs. The area drawn upon depends upon the size of the rindbreak, but usually it is not greater than 50 feet each way.

To prevent this, wide root extension must be limited and the sheltering trees forced to root into deeper soil layers. This can be accomplished without injury to the shelter belts, by running a parallel trench 6 to 10 feet from them. The trench should be dug 3 or 4 feet deep, cutting off the surface roots of the gum trees, then refilled to prevent the roots from dipping beneath it to seek the orehard. The roots will then spread out in the loosened soil of the trench, which should be reopened about every second year to restrain their extension beyond it. The result is to compel deep rooting. which is attested in numerous orchards by the heary production of citrus trees in rows adjacent to the windbreak.

Commercial Plantations. With the exception of a few small, suattered groves of black locust, planting for timber production in California has been confined to the eucalypts and chiefly to the blue gum. This species has been grown extensively in Southern California for fuel, and except for small amounts of oak, juniper, mesquite and pine has supplied the section for the past thirty years.

The returns on investments in Eucalyptus plantations have been generous, in many cases exceeding those received from equal areas under cultivation in orchards or agricultural crops. Groves set out in the fertile Los Angeles valley have yielded from 50 to 80 cords per acre at every entting. Yields of 75 cords per acre every seven or eight rears have been frequent.

At the present time there are several thousand areses in California planted to Eucalyptus. The following is a partial list of the larger fuelwood groves :

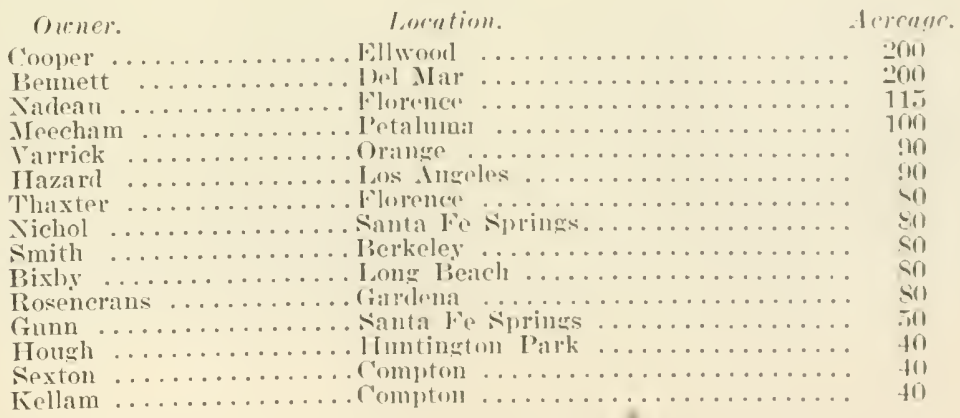




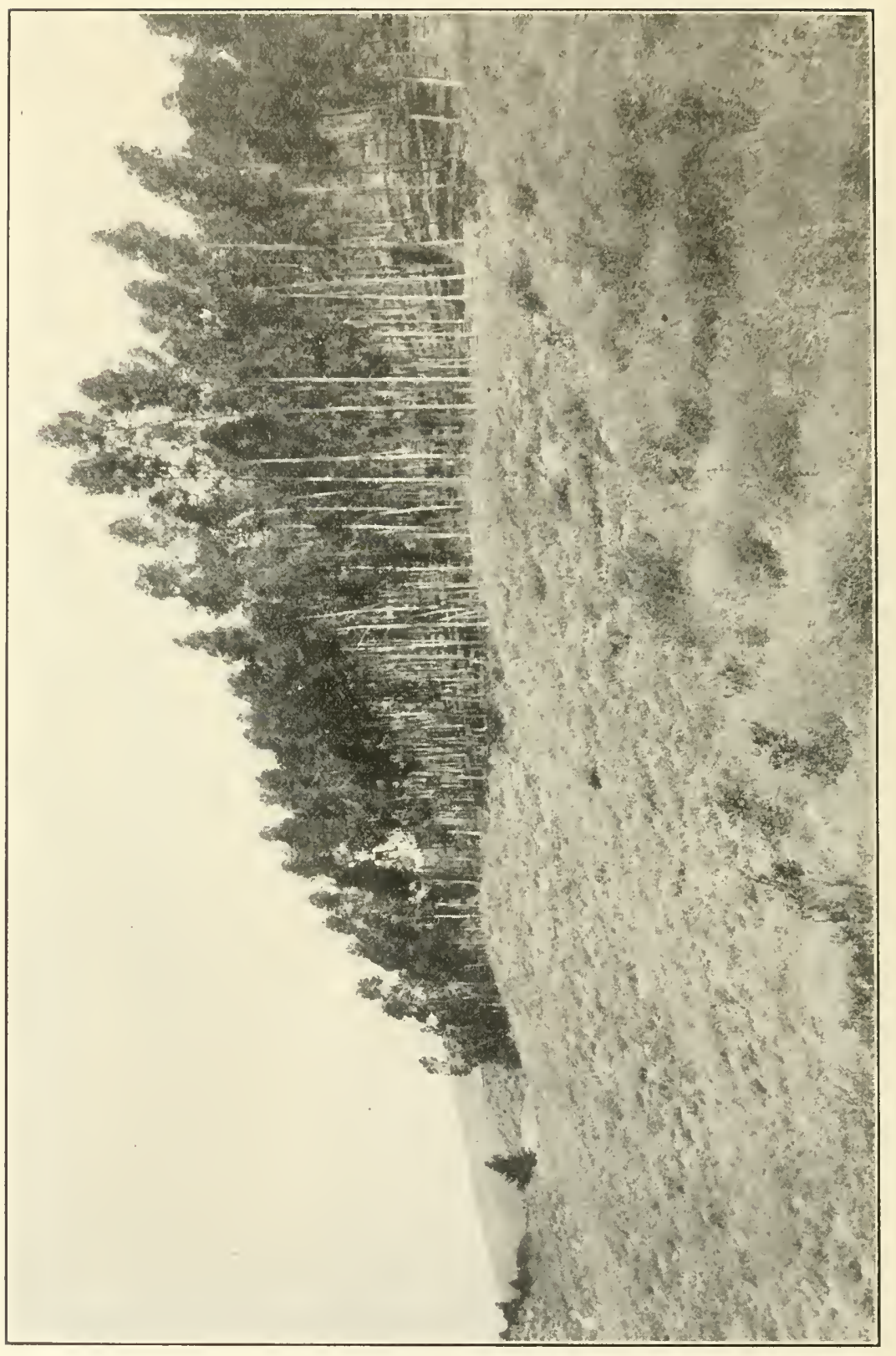




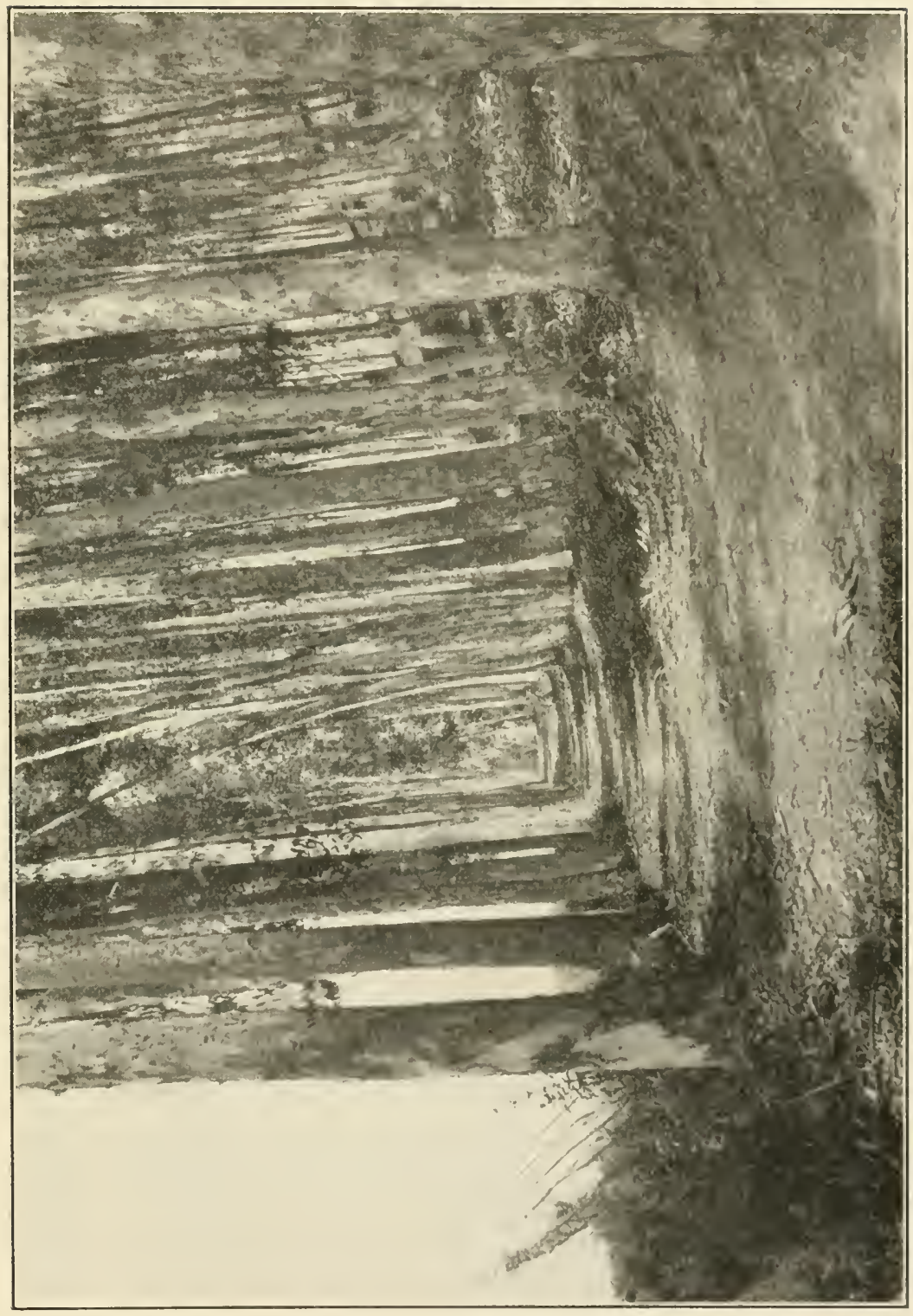


In recent year's several plantations of large size have been established in anticipation of a market for grum wood of merchantable size or for poles, piles, and railroad ties.

The plantation of Mr. Dwight Whiting at El Toro, Orange County, now covering 1,000 acres, is the most extensive commercial plantation in the State. Its oldest portions are now three years old. Planting will be continued annually until a forest of 4,000 acres is established. The plantation consists almost entirely of gray, red, and sugar gums.

The Bixby Company of Long Beach has begun the planting of an area of about 3,000 acres near Orange, Orange County. Blue, gray, lemon and sugar gums, in varying proportions, will be used.

The Santa Fe Railroad Company has recently acquired a tract of 8,600 acres in San Diego County, which will be devoted to Encalyptus production to supply the eompany with poles, piles, ties, and other timber. The gray, lemon, sugar and blue gums will be planted.

The Union Lumber Company, located at Fort Bragg, Mendocino County, is the first lumber organization to become interested in the commercial planting of Eucalyptus. This company has cut over an area of 10,000 to 15,000 aeres of redwood during the course of its operations. The logged redwood lands do not naturally restork with merchantable timber, because spaee between stumps afford too much entrance to lateral light, eausing the production of limbs and hence knotty timber. Eucalyptus will be planted between the clumps of coppice shoots to cut off the lateral light and force the redwood secondgrowth into height development.

The Central Counties Land Company, which has recently acquired extensive holdings on and near Clear Lake. Iake County, has begun the propagation of blue and sugar gum seedlings for planting on its lands hoth for ornamental and eommercial purposes.

The Paeifie Electric Company and the Ontario Power Company have recently acquired smaller tracts in Riverside and San Bernardino counties, upon which they have begun planting with several speeies of Eucalyptus to raise tie timbers and poles for electric wiring. Extensive commercial planting is also being undertaken by many other companies and individual landowners in several different seetions of the State. It is apparent that much greater attention to Eucalyptus planting may be experted in the near future.

\section{TIMBER UTILIZATION.}

Fueluood. In Southern California the use of gum fuelwood has been most general. Gum cordwood is a staple fuel and may be found on sale in woodyards in most of the valley sections of the State. In the northern valleys it is much less rommon than in Southern California. owing to 
its greater scarcity and the competition of valley oals, which have been slanghtered regardless of their value for ornament and shade. Fuel oils have supplanted fuelwood to some extent, yet in Southern California, where fuel oils are available, fuelwoods have never been disposed of at a sacrifice.

Eucalyptus wood has high fuel value. It makes a quick, hot fire. hence it is very suitable for cooking purposes and for use in open fireplaces. It burns with a bright blaze and emits a pleasant, aromatie odor. In heating qualities it is hardly inferior to California oak wood. Most consumers are prejudiced in favor of oak wood, however, hence gum wood commands a lower price in the market than oak or mesquite. In different localities the price of gum fuelwood varies from $\$ 5$ to $\$ 14$

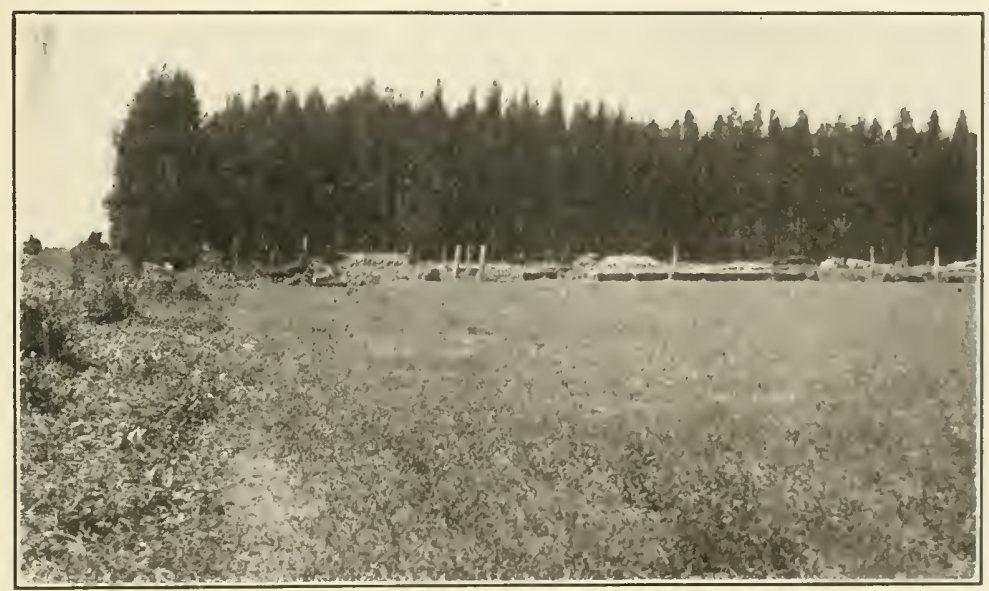

PLATE 9. Cutting a 6-year-old stand of lulue gum for fuel. l'ortalile sawing and splitting machine and piled cordwood in foreground. stand averages 80 foret in leight. Five acres cut yiolded 3.50 california cords.

per cord, with tendencies toward the latter. Wood of the slower-ryowing eucalypts and that of old trees possesses higher value than young wood from quick-growing sperejes. Green gum wood makes poor fuel.

Gum wood is sold by the short rord of 96 instead of 125 rulife feet. two tiers of rood, 10 to 18 inches long. piled 8 feet long and $t$ feet high. constituting a cord. 'l'en-inch wood is generally sold at the same price as 18-inch wood. withont protest hy the consumer. The wood rut from the rapid-grown gum sprouts is manuly sapwood, which shrinks greatly in drying. A cord will lose 15 per eent or more of its rolume in seasoning.

Cordwood for the market is usually ent from tall, slender, sproutgrown trees rarely over 8 iuches in diameter. The trees are sawed into fuel lengths without peeling the bark. If left in the round the sticks 
do not bum as well as if split. Splitting must not be delayed after cutting, as the wood becomes very hard upon drying. Wood of sugar and red gum is quite straight-grained and splits without difficulty. Blue gum wood, particularly the sap-wood of old, open-grown trees, is very tongh and cross-grained. The interlocked fibres must be chopped through in splitting and seasoned blocks defy all attempts to split them with an ax.

A small industry has grown up in Southern California through the cutting of blue gum groves for fuel. Traveling cutting concerns undertake the cutting of groves by contract, employing gangs of choppers and operating portable sawing and splitting machines in working up the product. The cost of eutting varies with the cost of labor from $\$ 2$ to $\$ 3$ per cord, and a margin of from $\$ 3$ to $\$ 8$ profit is left the owner, according to the advantage with which the wood is sold and its nearness to market.

Green wood should be piled for seasoning away from contact with the ground. The wood decays rapidly in contact with the soil and soon loses its fuel value.

A superior grade of charcoal can be made from gum wood. Where old groves are rooted up after repeated cuttings, the massive stumps are frequently burned for charcoal, and cordwood has likewise been used to some extent for this purpose.

Posts. A supply of strong, durable fence posts is one of the greatest needs of the California rancher. At present, dependence is placed in redwood and to a limited extent in local plantations of black locust. The hardness and strength of Eucalyptus wood would justify its use for posts if it were more durable in eontact with the soil. Certain species, notably sugar and red gum, are of average durability.

Round blue gum posts from sapling groves have been used to some extent, but without satisfactory results. Split or sawn posts of more mature timber would doubtless last much longer, but these have not been widely used owing to the difficulty of splitting the wood. It is apparent that Eucalyptus has fallen into disrepute for post purposes without receiving a thorough trial.

Experiments in seasoning and treating Eucalyptus to determine its durability under better treatment have been undertaken recently by the Forest Service in coöperation with the State of California. Thousands of posts, of the size ordinarily used, were ent from young sprout plantations. Some were set green and unpeeled, others peeled and seasoned. Still other posts, green, seasoned, peeled, and mpealed were impregnated with hot creosote for different lengths of time in small portable tanks. They were then given distinguishing marks and set in fence lines in soils of different kinds. 
Examinations of the posts will be made from time to time to determine their durability under different methods of treatment. The experiment, when coneluded, will demonstrate whether blue gum may be used to advantage for post material.

Red, blue, sugar and red iron bark gums were used. It was found that all yielded to treatment remarkably well. The arerage cost per post was 6 or 7 cents for preservative alone. To this must be added the minor cost items. labor and wear of apparatus. The greater durability of treated gum posts is still unknown, but judging from the increased life of other inferior woods after treatment, and the known value of creosote as a preservative, it is safe to predict an increased durability all out of proportion to the eost of treatment.

Poles. A large amount of timber is used annually for poles for electric wiring. The increase in value has almost prohibited the nse of the much preferred Oregon pine (Pscudotsuga taxifolia), and pole timbers of lower grade have come into use. Oregon eedar from which from six to fifteen years' service is obtained, depending on the character of the soil in which the poles are set, is the chief substitute. Experiments are also being condueted looking toward the substitution of yellow pine and yellow eedar. Encalyptus poles have been tried to a limited extent, and may be expected under treatment to outlast the pole timbers in present use.

L'ailroad Ties. The development of transcontinental, interurban and urban railways has created a strong demand for timber suitable for ties. Encalyptus timber has not yet come into general use for ties. although the indications are that it will be used more extensively in the future. The value of the wood for tie use has been tested by the Sonthern Paeific Company. Some hundreds of ties of California-grown blne gum were laid green and untreated in sandy soil in the roadbed through central Nevada. They exhibited good wearing qualities and the requisite strength, but, through lack of proper seasoning, ehecked badly, so that in some cases they failed to hold the spikes. At the end of four years the ties showed no signs of deeay; after seren years' service some were worthless from deeay, but some were sound at the end of eleven years.

The result of the experiment offieially reported to the company eredited the gum ties with being equal to the best second grade Sonthern pine, but the experiment was not followed by more extensive use. Gum timber ean not compete with the best tie timber in durability, but if the life of gum wood is extended ly preservative treatment its wearing qualities will make it a superior tie timber.

With inerease in cost of redwood and pine timber, lower grade ties of the more durable eucalypts should find a place in the market. Sea- 
soned gray, red and stogar gom timbers are moderately durable and should give longer service than bhe gum. Sugar gum is probalily the best encalypt for tie production.

Mine Timbers. Blue and sugar gum have heen used with sucress in limbering mines near Escondido. The gum timber has bern found superior to any other obtainable there. Few of the timbers have decayed, although the mines are flooded during a part of each rear. Difference in value of the two species has not ret hecome apparent. hut it is probable the sugar gum will prove superior, as it excels blue grum in both strength and durability.

Wharf Piling. 'The problem of maintaining wharves has become an important one on the Pacific coast. Not only are the best pile timbers very expensive, but they will not resist the attacks of the teredo and limnoria and have to be replaced continually.

Both the teredo and limnoria are troublesome all along the Pacifie eoast, being carried from port to port by the shipping. The terecto attacks the piling at the ground line. under water, and burrows chambers through the rood. When the piling is mprotected. this source of injury is generally negligible, for the timbers are more speedily eaten off at the water line by the limmoria. The limnoria have no natural enemies in Anerican waters to decimate their numbers, hence they are constantly increasing and becoming more troublesome. Their attacks are particularly severe in the warm waters of the southern ports and in sheltered harbors.

In an attempt to maintain durable wharves, experiments have been made with costly iron and cement piles, but the lower cost and greater ease of setting keeps the wooden pile in favor. Tarious expensive treating and sheathing experiments have been tried, but preservative processes have failed so far to eheck the borers. Limmoria will not attack wood which is coated with sand. This fact has been taken advantage of to defeat them by applying a rough cement rash to the exposed surface of the piles. This coating not being elastic, however. fails to prevent the limnoria from entering at season cheeks and continuing their work under the cement covering. Pile timbers are generally ereosoted or oiled, and often wrapped and battened, to increase their period of service, but limnorias attack even creosoted wood. When untreated. piles are generally set unpeeled, as the borers do not work while the bark remains.

Aside from its use for fuel, gum timber has been most extensively used for piling. After extended trial the blue gum pile has been determined the best in nse on the Parifie coast. Whenerel it can be obtained, contractors and wharf managers discriminate in its faror. 
It is attacked and ultimately destroyed by borers, notwithstanding contrary statements. Its superiority serms to lie in its extreme hardness, for when gum and softwomd piles are nsed together in a wharf. the horers concentrate their attack on the softer piles. Experienced

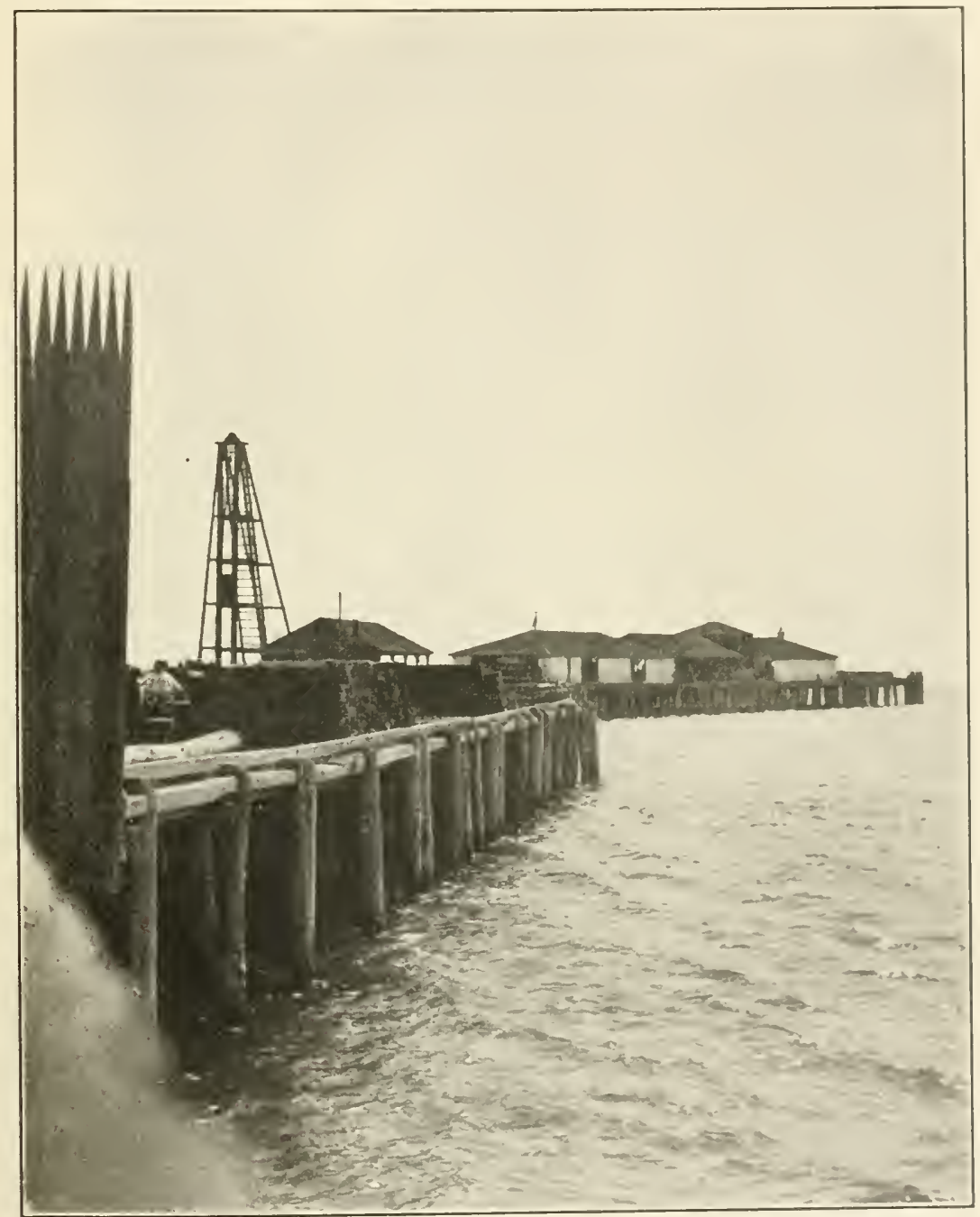

PLATE 10. Blue gum piling in the wharf at Santa Barbara.

users diseriminate in faror of piles from old. slow-grown freses ant during the winter and seasoned thoroughly.

Eucalyptus piles in general use are from 30 to 3.5 feet long and from 12 to 24 inches in diameter. Such piles hring from t. to $\$ 15$ apiece on the stump. 
Gum piling was first used in the wharf at Santa Barbara. Its use in some other wharves was acciclental, but since its successful trial it has been used in the wharves at Creseent City, Oakland, Port Harford. Gaviota, Santa Barbara, Serena, Summerland, Avalon, Oreanside and San Diego. On arcount of its superior service it is used in the wharf at Crescent City despite the local supply of redwood timber.

Dimension Material. No valuable hardwood timber is native to California or the Paeific eoast. Demands for it have been supplied ly importation from Eastern centers of production at high prices and high freight rates. Euealyptus has been widely used for saw-timber in Australia, but in California its commonness has prejudiced users against it. Added to this is the faet that very little dimension material has been produced, practically all the plantations having been cut for fuel. At present it ean hardly be found in the market.

Pioneer manufacturers, operating planing mills in San Francisco. Los Angeles and San .Jose. have persevered for twenty years in utilizing. it as ordinary hardwood stock. Diffieulty has been encountered in the introduction of a new material, however. so their business has remained small. They have overeome local prejudice to some extent by guaranteeing their product. Severe and extended trial has proven that it possesses superior qualities of strength, hardness and flexibility. Seasoned blue gum timber has been substituted in San Francisco for orders of maple, hickory, and "ironwood" withont the knowledge but to the entire satisfaction of the purehaser.

No fixed stumpage price for Eucalyptus timber prevails. It is bought either by the single tree or at the market price of cordwood. Large trees which contain 4 to 6 cords, or will eut 1.500 to 3,000 feet B. MI.. are hought for from $\$ 12$ to $\$ 25$ per tree. The total eost of stumpage. logging, manufacturing and seasoning is about $\$ 20$. hence it is apparent that manufacturers can readily undersell Eastern hardwoods. Gum timber has been sold at from $\$ 100$ to $\$ 125$ per $\mathrm{M}$, and retails for 1212 cents per foot for finished and 10 eents for rough timber.

\section{QUALITIES OF EUCALTPTUS TrOOD.}

The timber encalypts furnish a hardwood possessing qualities similar to those of Eastern hickory and ash. The wood of different species differs in strength and durability. but in general the timber is very strong, heavy and hard, with a close-grain and homogeneous struı.ture.

The speeific gravity of the rood of most speeies is greater than that of water, the dry wood of blue gum averaging over 60 pounds per cubic foot, varying from 50 to 70 pounds, according to the age of the timber. The wood of other species is still heavier. It is very tough. resisting indentation, tension or torsion. This is of advantage, for it 
will not erack nor break out under strain at joints or bolt holes. The wood is stiffer and less elastic than Eastern hickory.

The wood of different speeies ranges in color from white to dark brown. The heart and sapwood of many species is indistinguishable. The heart of blue gum is a little darker than the sapwood, while that of red gum is red or dark brown in color. The grain of blue gum closely resembles that of hickory and ash.

\section{SEASONING.}

The difficulties experienced in seasoning Eucalyptus timber have been a great obstacle to its more extensive utilization. It has received an undeserved reputation for warping and checking from many who have used it green or improperly seasoned. It is no more difficult to season than oak, hard maple and many other hardwoods. which are annually cut and seasoned by the million feet in the Eastern States. The success attained by several experienced mamufacturers proves that it vields readily to thorough methods.

To insure successful seasoning the trees should be felled between November and Narch. Sawlogs should be manufactured as soon as possible after cutting. for they eheck quickly with exposure to sun and winds. When not to be sawn immediately, they should be piled in the shade without peeling. The ends of the logs should be painted to prevent eheeking.

Ordinarily, sawn lumber shoukd be loose-piled under anver with abundant space for air circulation. The ends of the timbers should he weighted. By this treatment 6 by 8 inch or larger timber's are thoroughly and evenly seasoned withont warping or checking. thongh the wood may shrink considerably during the seasoning process. Inch boards are apt to warp in seasoning, so the lumber is usually sawn into planks. The heartwood is more apt to check than the sapwood.

Air seasoning prodnces better results than kiln seasoning. Air-dried lumber may be used in a year, but two years' seasoning gives hetter results and is generally practiced.

\section{USES OF LUMBER.}

Tchicle Parts. Blue gum has been extensively used as a substitute for other hardwoods in the mamfacture of rehicles. Its strength and elasticity recommend it very highly as a substitute for hickory and asl. which are rapidly becoming scarce. Gum timber is just as durable and nearly as strong as hickory. If kept from contact with the soil. it will not decay under exposure to the weather, and will retain its shape if properly seasoned.

Its usefulness for vehicle parts has been recognized locally for a long time. The ranchers of the Los Angeles and Santal Clara valleys 
have used it for poles, shafts, reaches, axles, doubletrees, racks, bolsters, spokes. luubs and felloes and for the wooden parts of plows, harrows and other agricultural implements. Like its first use for piling, Encalyptus was first employed for vehicle parts by accident.

Recently gum wood was experimentally used for wooken ties on heary auto trucks. The motors of these vehicles are damaged and bolts are soon cut off by the jar of running on steel rims on city parements. and expensive sets of rubber tires last but a few months. A wooden tire was derised by bolting seasoned blocks of gum wood. set with the grain vertical, into a patent rim attached to the wheels. The tires have been used succesfully for six months without attention or ronair and show few signs

up vibrati;

Insulate

wood for

the manuf

grown gum

to take

been filled in Canada and the Eastern States. Gum pins are in use in most of the telephone and power transmission lines in this State, and are used exclusively by leading contractors. Sound pins are still in use after' fifteen years' service.

Furmiture. Seasoned blue and red gum wood has been used to a limited extent for cabinet work and for the manufacture of furniture. Handsome chairs and tables have been made, which are very strong and do not warp, check or loosen at the joints. The wood takes a splendid finish and has been stained to imitate mahogany very closely.

Other Ises. In a few instances unstained panels, showing fine grain, have been used in the interior finishing of houses. The timber has also been manufactured into flooring and used in place of hard maple. It has been used for pulley blocks, belt wheels, saw tables, brakeshoes, for levers of house-moving windlasses, and, indeed, most generally where a durable wood of homegeneous structure is required.

\section{BOTANICAL NAMES.}

A list of the botanical names of the species mentioned in this report follows :

Common Names.

Scientific Tames.

Blue Gum ....................... Lucalyptus globulus.

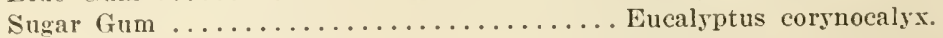

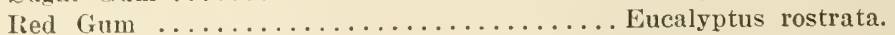

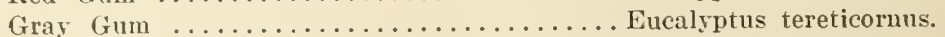

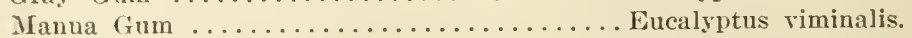

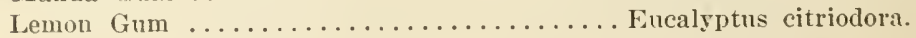

